OPEN ACCESS

Edited by:

Johannes Felix Buyel, Fraunhofer Society (FHG), Germany

Reviewed by: Johan Nilvebrant, Royal Institute of Technology, Sweden Tae Hyun Kang, Kookmin University, South Korea

${ }^{*}$ Correspondence:

Karla Mayolo-Deloisa kmayolo@tec.mx

${ }^{+}$These authors have contributed equally to this work

Specialty section: This article was submitted to Bioprocess Engineering, a section of the journal Frontiers in Bioengineering and Biotechnology

Received: 30 May 2021 Accepted: 09 August 2021 Published: 20 August 2021

Citation:

Sánchez-Trasviña C, Flores-Gatica $M$, Enriquez-Ochoa D, Rito-Palomares $M$ and Mayolo-Deloisa K (2021) Purification of Modified Therapeutic Proteins Available on the Market: An Analysis of Chromatography-

Based Strategies.

Front. Bioeng. Biotechnol. 9:717326. doi: 10.3389/fbioe.2021.717326

\section{Purification of Modified Therapeutic Proteins Available on the Market: An Analysis of Chromatography-Based Strategies}

\author{
Calef Sánchez-Trasviña ${ }^{1 \dagger}$, Miguel Flores-Gatica ${ }^{1 \dagger}$, Daniela Enriquez-Ochoa ${ }^{1 \dagger}$, \\ Marco Rito-Palomares ${ }^{2}$ and Karla Mayolo-Deloisa ${ }^{1 *}$ \\ ${ }^{1}$ Tecnologico de Monterrey, Escuela de Ingeniería y Ciencias, Centro de Biotecnología-FEMSA, Monterrey, Mexico, ${ }^{2}$ Tecnologico \\ de Monterrey, Escuela de Medicina y Ciencias de la Salud, Monterrey, Mexico
}

Proteins, which have inherent biorecognition properties, have long been used as therapeutic agents for the treatment of a wide variety of clinical indications. Protein modification through covalent attachment to different moieties improves the therapeutic's pharmacokinetic properties, affinity, stability, confers protection against proteolytic degradation, and increases circulation half-life. Nowadays, several modified therapeutic proteins, including PEGylated, Fc-fused, lipidated, albumin-fused, and glycosylated proteins have obtained regulatory approval for commercialization. During its manufacturing, the purification steps of the therapeutic agent are decisive to ensure the quality, effectiveness, potency, and safety of the final product. Due to the robustness, selectivity, and high resolution of chromatographic methods, these are recognized as the gold standard in the downstream processing of therapeutic proteins. Moreover, depending on the modification strategy, the protein will suffer different physicochemical changes, which must be considered to define a purification approach. This review aims to deeply analyze the purification methods employed for modified therapeutic proteins that are currently available on the market, to understand why the selected strategies were successful. Emphasis is placed on chromatographic methods since they govern the purification processes within the pharmaceutical industry. Furthermore, to discuss how the modification type strongly influences the purification strategy, the purification processes of three different modified versions of coagulation factor IX are contrasted.

Keywords: chromatography, purification, PEGylation, lipidation, Fc-fusion, biopharmaceuticals, protein modification

\section{INTRODUCTION}

Within the pharmaceutical industry, biopharmaceuticals have become a continuously growing category in recent years (Papathanasiou and Kontoravdi, 2020). In the last 19 years, more than 300 biopharmaceuticals were approved (Tihanyi and Nyitray, 2021). In 2018, biopharmaceuticals accounted for almost $40 \%$ of the total drug research and development pipeline worldwide; while global sales reached nearly USD 228 billion in 2016 (Moorkens et al., 2017; Lloyd, 2018). Among biopharmaceuticals, therapeutic proteins have been recognized as the most important biologicals in terms of clinical utility (Dimitrov, 2012). From 2014 to 2018, 68 monoclonal antibodies, 23 


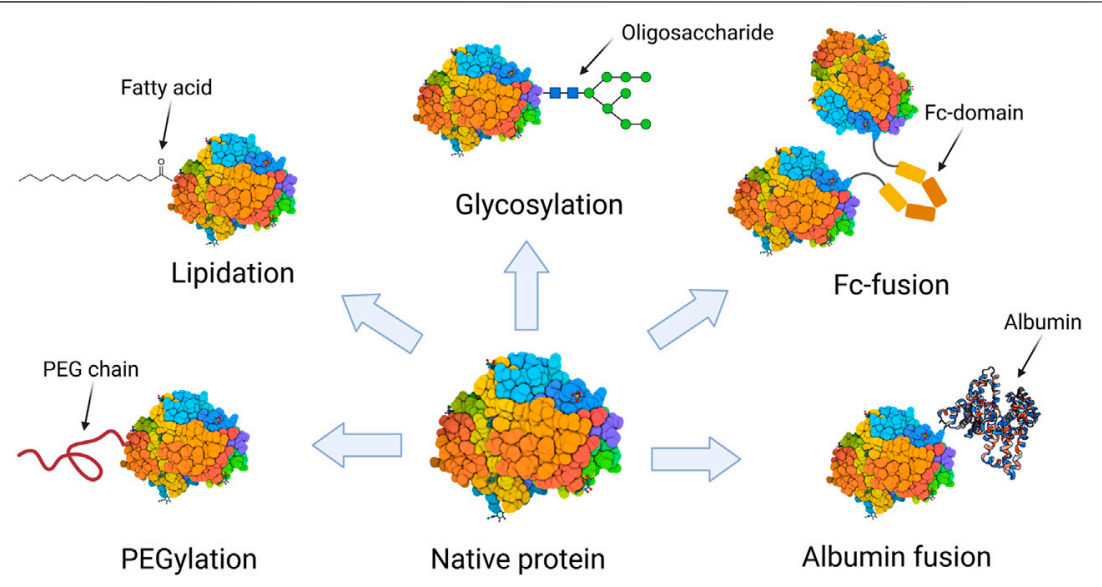

FIGURE 1 | Schematic representation of the protein modification approaches that are present by at least one biopharmaceutical on the market.

hormones, 16 clotting factors, and nine enzymes were approved in the United States and the European Union (Walsh, 2018). In 2020, the global sales of therapeutic proteins reached USD 90.53 billion, and it is expected to reach more than USD 155 billion in 2025 (Research and Markets, 2021).

Therapeutic proteins (including native, recombinant proteins, and monoclonal antibodies) have been used successfully for a wide variety of treatments including the restoration of native biomolecules activity, integration of non-present proteins, control of metabolic pathways, and even cancer (Pelegri-O' Day et al., 2014). From a therapeutic perspective, they offer superior advantages over conventional drugs, such as being highly specific and providing complex functions, having a high biological activity, and less risk of side effects (Pisal et al., 2010). However, there are several limitations associated with their use (excluding to monoclonal antibodies), such as short half-life within the body, low solubility, physicochemical instability, susceptibility to proteolytic degradation, and immunogenicity (Pfister and Morbidelli, 2014). Protein modification has emerged as a strategy to overcome these challenges.

Protein modification involves the conjugation or fusion of a protein to a specific moiety, such as polymers, lipids, glycosides, peptides, protein domains or another proteins (Strohl, 2015; Veronese and Pasut, 2007). Despite that many protein modification approaches using different moieties have been proposed, just a few of them have become widely adopted for therapeutic proteins (Figure 1). Modification with polyethylene glycol (PEG) moieties has undoubtedly become the most used. Since the approval of the first PEGylated protein in 1990, Adagen ${ }^{\circledR} \quad$ (a PEG-conjugate adenosine deaminase), 29 PEGylated protein biopharmaceuticals have been approved and are currently available on the market. Another commonly used approach to improve therapeutic proteins' pharmacokinetics is the fusion to the Fc domain of immunoglobulin G (IgG). In 1998, Enbrel ${ }^{\circledR}$ became the first Fc-fusion protein to be available on the market and thence $12 \mathrm{Fc}$-fusion proteins have obtained regulatory approval (Jafari et al., 2017). Other protein modification approaches, such as lipidation, albumin-fusion, and glycosylation have gained increasing interest over the past years. Nevertheless, they still have a reduced presence on the market. To date, there are only six lipidated proteins, one glycosylated protein, and one albuminfusion protein approved for therapeutic use in human subjects (van Witteloostuijn et al., 2016; Lagassé et al., 2017).

To obtain regulatory approval and successfully reach the market, therapeutic proteins must be manufactured under conditions that ensure their safety and efficacy. This is not a trivial process. Therapeutic proteins are generally produced using living cells or microorganisms (Lagassé et al., 2017). Moreover, proteins need to maintain their three-dimensional structure to be biologically active, which involves not only the correct sequence of amino acids but also proper folding and specific posttranslational modifications (Chaudhary et al., 2017). Since therapeutic proteins are synthesized using cell-based production systems, complex purification strategies are generally involved. Several contaminants including DNA, cell debris, endotoxins, host cell proteins, media components, and viruses must be removed. Additionally, protein modification increases the complexity of purification even further, as more impurities may be added to the process, such as unreacted protein, reagents, or multiple less functional isomers. Currently, most purification processes for modified therapeutic proteins are based on chromatographic techniques. This may be explained by its multiple advantages over other methods, such as having a high resolution and robustness, and presenting high recovery levels (Przybycien et al., 2004; Gottschalk et al., 2012). To obtain the highest yield and purity, selection of a specific chromatographic technique and optimization of operating conditions are essential.

Numerous previous reviews describe the history, types of reactions, and purification strategies used for modified therapeutic proteins (Pfister and Morbidelli, 2014; Jafari et al., 2017; Jiang et al., 2018; Ramos-de-la-Peña and Aguilar, 2020; Duivelshof et al., 2021). However, they focus mainly on modified therapeutic proteins that have not reached the market yet and are still under development. This review presents a critical analysis of 
the chromatography-based purification strategies exclusively for all modified therapeutic proteins that have obtained regulatory approval and are currently commercialized. Based on such analysis, this review provides a guide for the selection of chromatography-based purification processes for novel modified therapeutic proteins. The information of the purification processes was mainly obtained from patents, as a primary source, or from the original reports associated to the design of the biopharmaceutical. This work is divided by modification type: PEGylation, Fc-fusion, and lipidation, while glycosylation and albumin-fusion are discussed in a single section given the low number of biopharmaceuticals from these categories currently on market. Within each section, a brief introduction of the modification strategy is presented, followed by an analysis of the purification process parameters (i.e., chromatographic technique, stationary phase, elution mode, etc.). Afterwards, coagulation factor IX, the only therapeutic protein with three different modifications on the market, is presented as a case study to demonstrate how the modification greatly influences the development of chromatographic processes. Finally, the current challenges to develop more efficient chromatography-based purification processes are summarized.

\section{PEGYLATION}

PEGylation is the linking of one or more PEG molecules to a protein by means of a covalent bond (Pfister and Morbidelli, 2014). PEG is a synthetic polymer comprising repeating units of ethylene oxide with the following general molecular structure: $\mathrm{HO}-\left(\mathrm{CH}_{2}-\mathrm{CH}_{2}-\mathrm{O}\right)_{n}-\mathrm{H}$. It is a biocompatible, neutral, highly water-soluble, and flexible polymer that exhibits a random coil conformation (Fee and Van Alstine, 2011). After the PEGylation reaction, proteins acquire new features, such as increased physical and thermal stability, increased water solubility, proteolytic protection, and extended circulation half-life; properties that enhance the native protein's pharmacokinetics and therapeutic efficacy (Pfister and Morbidelli, 2014).

PEGylation can be carried out using different strategies depending on the nature of the protein and desired application. The covalent attachment of PEG chains occurs at chemically reactive residues, often exposed at the surface of the protein, including lysine, cysteine, serine, histidine, arginine, tyrosine, threonine, aspartic acid, and glutamic acid; or at the $\mathrm{N}$ - and C-terminus. For this reaction to occur, the PEG chain must be functionalized at one end with an active group (activated PEG), which is chosen depending on the available residue(s) in the protein. It is worth mentioning that, prior to PEG conjugation, the protein must be already pure to increase the yield of the reaction (Pfister and Morbidelli, 2014; Ramos-de-laPeña and Aguilar, 2020). Nevertheless, depending on the PEGylation reaction strategy, the products may include a heterogenous mixture of mono-, multi-PEGylated products (proteins with a varying number of attached PEG molecules), and/or positional isomers (proteins with the same number of PEG chains that differ from each other in the location of the PEG molecule). All of these differ in physicochemical and pharmaceutical properties (Swierczewska et al., 2015). Moreover, at the end of the PEGylation reaction unreacted PEG and native (unmodified) protein may still be present. PEGylated species and reactants are separated mainly by chromatography in its different operational modes (Figure 2).

PEGylation is a highly successful modification strategy as reflected by the large number of PEGylated proteins that have been approved and are available on the market. Table 1 summarizes the purification processes for these proteins, which largely depend on a specific protein and PEGylation reaction. It should be mentioned that in large-scale manufacturing processes, the purification strategy employed (chromatography mode or stationary phase) might be different to that reported at lab-scale/early development. Moreover, it is important to notice that not all the purification processes of PEGylated proteins rely on chromatographic techniques. In the cases of Adagen $^{\circledR}$, Revcovi $^{\mathrm{TM}}$ and Palynziq ${ }^{\circledR}$, only an ultrafiltration step is employed to remove unreacted PEG (Davis et al., 1981; Vellard et al., 2008; Filpula and Sapra, 2014; Bell et al., 2017). The conformation and size of these conjugates (PEG chains of 14,13 and $36 \mathrm{kDa}$ linked to Adagen ${ }^{\circledR}$, Palynziq ${ }^{\circledR}$ and Revcovi ${ }^{\mathrm{TM}}$, respectively) allow their separation from the native protein and unreacted PEG by ultrafiltration membranes (Molek and Zydney, 2006). Unfortunately, for some PEGylated proteins, specifically biosimilar products of Neulasta ${ }^{\circledR}$, the information regarding their purification processes is not available.

\section{Chromatography-Based Approaches}

The main chromatographic technique used to purify approved and commercialized PEGylated proteins is ion exchange chromatography (IEX), either anion exchange (AEX) or cation exchange (CEX) chromatography (Table 1). IEX has been extensively used in downstream processes for capture, intermediate and polishing steps (Pfister and Morbidelli, 2014). This chromatographic technique allows the simultaneous separation of the native protein, unreacted PEG, mono- and multi-PEGylated species, and even positional isomers (Seely and Richey, 2001; Gašperšič et al., 2016; Nguyen et al., 2016). The PEGylation reaction can alter the superficial charge of the protein. The PEG chain produces a "charge shielding effect" and generates weak electrostatic interactions with the resin (Nguyen et al., 2016). Furthermore, if PEGylation takes place on a charged amino acid residue within the protein (i.e., lysine or arginine), this is neutralized and in consequence the isoelectric point ( $\mathrm{pI}$ ) of the conjugated protein is altered. Moreover, hydrogens from the PEG chain can form hydrogen bonds with some functional groups of the protein and raise the $\mathrm{pKa}$ (Fee and Van Alstine, 2011).

High resolution and purity can be obtained using IEX by choosing optimal operating conditions. These conditions are the operation mode (bind-elute or flow-through), elution mode (linear or step gradient), stationary phase, sample load, mobile phase (type, concentration, and $\mathrm{pH}$ ), elution type (ionic or $\mathrm{pH}$ ), elution buffer (type, concentration, and $\mathrm{pH}$ ), gradient length, flow rate, and column dimensions (Ahamed et al., 2008). From the 


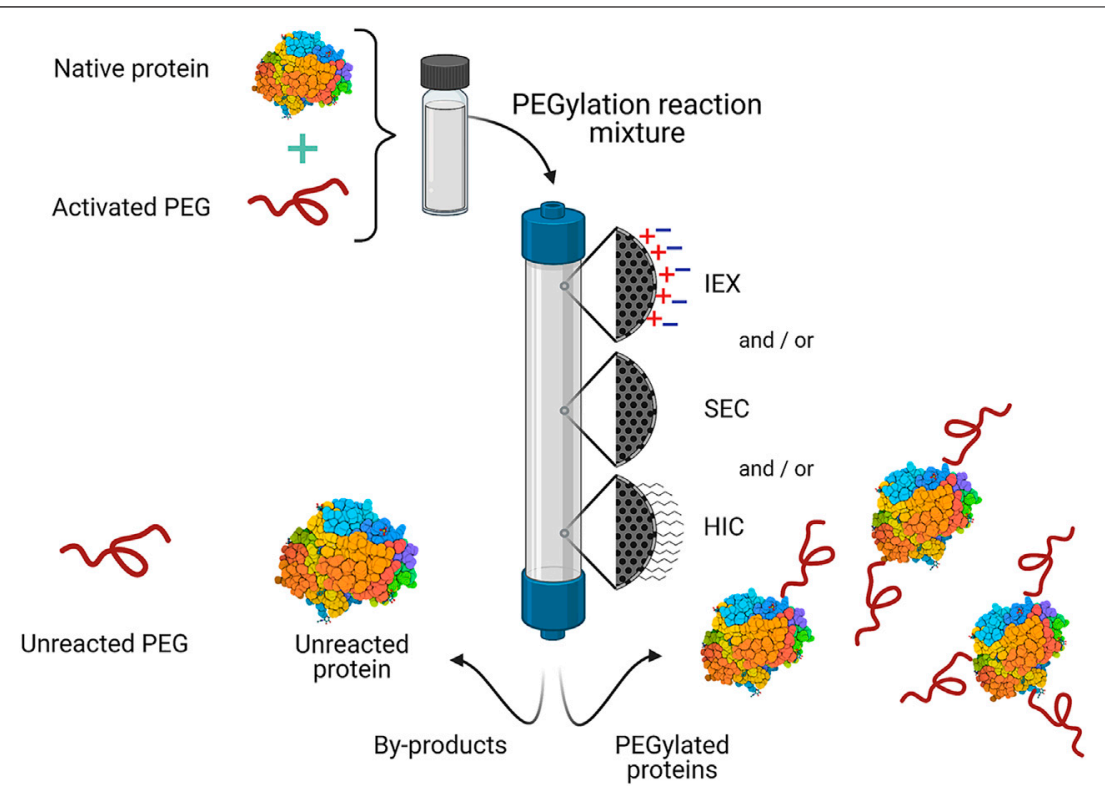

FIGURE 2 | General scheme for the purification of commercial PEGylated proteins by chromatography. One or more chromatographic operational modes are used to separate the desired PEGylated protein(s) from the PEGylation reaction mixture. IEX, ion exchange chromatography; HIC, hydrophobic interaction chromatography; SEC, size exclusion chromatography.

information available on purification processes for commercial PEGylated proteins, the operation mode and elution methods are highlighted. Most of commercial PEGylated proteins are purified using a linear gradient elution, with a bind-elute operation mode. A common method for protein elution in IEX is using a salt gradient. In IEX, protein adsorption is driven by electrostatic interactions between the stationary phase and the proteins (Shi et al., 2005). These interactions are in turn affected by the nature and concentration of salt (ionic strength) in the mobile phase. As the salt concentration increases, the retention of the protein decreases as a consequence of loss of electrostatic interactions (Staahlberg et al., 1991). Salt gradients generated by increasing sodium chloride $(\mathrm{NaCl})$ concentration (in a range from 0 to $1 \mathrm{M}$ ) prevail the most in the purification processes of commercial proteins $\left(\right.$ Neulasta $^{\circledR}$, Somavert $^{\circledR}, \operatorname{Krystexxa}^{\circledR}$, Mircera $^{\circledR}$, Cimzia $^{\circledR}$, Plegridy $^{\circledR}$, Adynovi $^{\circledR}$, and Esperoct ${ }^{\circledR}$ ) (Table 1). Only for the case of PEG-intron ${ }^{\circledR}$ (a $12 \mathrm{kDa}$-PEG interferon alfa-2b for chronic hepatitis $C$ ), the ionic strength of the mobile phase was modified by increasing the buffer components concentration (from 10 to $80 \mathrm{mM} \mathrm{Na}_{3} \mathrm{PO}_{4}$ ). The salt concentration range used to elute a PEGylated protein must be carefully selected. It will depend on the surface net charge of the protein and how it is affected by the modification. When the PEG chain slightly alters the surface net charge of the protein, it is desirable to use a narrow concentration range of $\mathrm{NaCl}$. This can be seen in the purification process of PEG-epoetin beta $\left(\right.$ Mircera $\left.{ }^{\circledR}\right)$, where the column was equilibrated with $100 \mathrm{mM}$ of $\mathrm{NaCl}$ and the PEGylated protein was eluted with $200 \mathrm{mM} \mathrm{NaCl}$ (Burg et al., 2011).

An alternative method to salt gradient for protein elution in IEX is to use a $\mathrm{pH}$ gradient. $\mathrm{pH}$ gradients are required to separate proteins with small differences in the isoelectric point (pI), which can be generated by positional isomers of PEGylated species. Cation exchange resins featuring weak acid groups have been used effectively to purify proteins exploiting $\mathrm{pH}$ gradients (Pabst and Carta, 2007; Pabst et al., 2008). For instance, in the downstream processing of Pegasys ${ }^{\circledR}$ (a $40 \mathrm{kDa}-\mathrm{PEG}$ interferon alfa-2a for chronic hepatitis B and C), it was possible to separate five different positional isomers by using a Toyopearl CM-650S resin (column dimensions: $16 \mathrm{~mm}$ diameter and $120 \mathrm{~cm}$ length) at a flow rate of $21 \mathrm{~cm} / \mathrm{h}$ and eluting with a linear $\mathrm{pH}$ gradient (from 4.0 to 7.8). Additionally, a preparative column packed with an analytical matrix (TSKgel SP-5PW) was used to increase the purity of the isoforms above $88 \%$ (Foser et al., 2003). In the purification process of Rebinyn ${ }^{\circledR}$ (a $40 \mathrm{kDa}$-PEG coagulation factor IX for hemophilia $\mathrm{B}$ ), a $\mathrm{pH}$ gradient is generated by equilibrating the column with acetate buffer $100 \mathrm{mM} \mathrm{pH} \mathrm{5.7,}$ followed by a five column volumes (CV) acidic wash with acetate

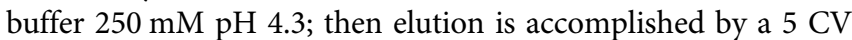
linear gradient of $10 \mathrm{mM}$ histidine, $50 \mathrm{mM} \mathrm{NaCl}, 50 \mathrm{mM} \mathrm{CaCI}_{2}$ buffer $\mathrm{pH} \approx 6.0$ (Stennicke et al., 2008; Wiendahl et al., 2020). Nevertheless, this approach, based on the affinity between the different buffer components to the stationary phase, is poorly implemented due to its drawbacks in practical applications. Because the column re-equilibration process becomes more complicated since the counterion of the elution buffer has a higher affinity to the support than the initial counterion (present in the equilibrium buffer), it is necessary to flush the column with the initial buffer at a higher concentration, and subsequently reequilibrate the resin to the buffer's initial concentration (Staby et al., 2009; Weiss, 2019).

On the other hand, size exclusion chromatography (SEC) is another chromatographic technique well recognized for the purification of PEGylated proteins. The PEGylation process of 
TABLE 1 | Approved PEGylated proteins.

\begin{tabular}{|c|c|c|c|c|c|c|c|c|}
\hline $\begin{array}{l}\text { International } \\
\text { non-proprietary } \\
\text { name }\end{array}$ & $\begin{array}{l}\text { Brand } \\
\text { name }\end{array}$ & Protein & Treatment & Company & CT & $\begin{array}{c}\text { Stationary } \\
\text { phase }\end{array}$ & $\begin{array}{l}\text { Approval } \\
\text { year }\end{array}$ & References \\
\hline $\begin{array}{l}\text { Pegademase } \\
\text { bovine }\end{array}$ & Adagen $^{\circledast}$ & ADA & $\begin{array}{l}\text { ADA severe } \\
\text { combined } \\
\text { immunodeficiency }\end{array}$ & $\begin{array}{l}\text { Enzon } \\
\text { Pharmaceuticals } \\
\text { Inc. }\end{array}$ & - & - & 1990 & Davis et al. (1981) \\
\hline Pegaspargase & Oncaspar $^{\circledR}$ & L-asparaginase & $\begin{array}{l}\text { Acute lymphoblastic } \\
\text { leukemia }\end{array}$ & $\begin{array}{l}\text { Enzon } \\
\text { Pharmaceuticals } \\
\text { Inc. }\end{array}$ & AEX & NA & 1994 & Turecek et al. (2016) \\
\hline $\begin{array}{l}\text { Peginterferon } \\
\text { alfa-2b }\end{array}$ & ViraferonPEG $^{\circledR}$ & IFN alfa-2b & Chronic hepatitis C & Schering-Plough & CEX & $\begin{array}{l}\text { TSKgel } \\
\text { SP-5PW }\end{array}$ & 2000 & $\begin{array}{l}\text { Gilbert and Cho, } \\
(1998)\end{array}$ \\
\hline $\begin{array}{l}\text { Peginterferon } \\
\text { alfa-2a }\end{array}$ & Pegasys $^{\circledR}$ & IFN alfa-2a & $\begin{array}{l}\text { Chronic hepatitis } \\
\text { B, C }\end{array}$ & $\begin{array}{l}\text { Hoffman-La } \\
\text { Roche }\end{array}$ & CEX & $\begin{array}{l}\text { Toyopearl CM- } \\
650 S \text {, TSKgel } \\
\text { SP-5PW }\end{array}$ & 2001 & $\begin{array}{l}\text { Karasiewicz et al. } \\
\text { (1995) }\end{array}$ \\
\hline $\begin{array}{l}\text { Peginterferon } \\
\text { alfa-2b }\end{array}$ & PEG-intron ${ }^{\circledR}$ & IFN alfa-2b & Chronic hepatitis C & Schering-Plough & CEX & $\begin{array}{l}\text { TSKgel } \\
\text { SP-5PW }\end{array}$ & 2001 & Gilbert and Cho (1998) \\
\hline Pegfilgrastim & Neulasta $^{\circledR}$ & G-CSF & Neutropenia & Amgen & CEX & $\begin{array}{l}\text { SP } \\
\text { Sepharose HP }\end{array}$ & 2002 & $\begin{array}{l}\text { Molineux (2004); } \\
\text { Bailon (2008) }\end{array}$ \\
\hline Pegvisomant & Somavert $^{\circledR}$ & $\begin{array}{l}\text { GH receptor } \\
\text { antagonist }\end{array}$ & Acromegaly & Pfizer & $\begin{array}{l}\text { HIC- } \\
\text { CEX }\end{array}$ & $\begin{array}{l}\text { Phenyl } \\
\text { Toyopearl } \\
650 M, \text { SP } \\
\text { Sepharose FF }\end{array}$ & 2003 & Clark et al. (1996) \\
\hline $\begin{array}{l}\text { PEG-epoetin } \\
\text { beta }\end{array}$ & Mircera $^{\circledR}$ & $\begin{array}{l}\text { Erythropoietin } \\
\text { (epoetin-beta) }\end{array}$ & $\begin{array}{l}\text { Anemia in adults with } \\
\text { chronic renal failure }\end{array}$ & $\begin{array}{l}\text { Hoffman-La } \\
\text { Roche }\end{array}$ & CEX & $\begin{array}{l}\text { SP } \\
\text { Sepharose FF }\end{array}$ & 2007 & Burg et al. (2011) \\
\hline $\begin{array}{l}\text { Certolizumab } \\
\text { pegol }\end{array}$ & Cimzia $^{\circledR}$ & Anti-TNF-alfa Fab & $\begin{array}{l}\text { Inflammatory } \\
\text { diseases }\end{array}$ & UCB Pharma & CEX & $\begin{array}{l}\text { SP } \\
\text { Sepharose HP }\end{array}$ & 2008 & Chapman et al. (1999) \\
\hline Pegloticase & Krystexxa $^{\circledR}$ & Uricase & Chronic gout & $\begin{array}{l}\text { Savient } \\
\text { Pharmaceuticals }\end{array}$ & AEX & Mono Q & 2010 & $\begin{array}{l}\text { Sherman et al. (2004); } \\
\text { Williams et al. (2003) }\end{array}$ \\
\hline $\begin{array}{l}\text { Peginterferon } \\
\text { alfa-2b }\end{array}$ & Sylatron ${ }^{\mathrm{TM}}$ & IFN alfa-2b & $\begin{array}{l}\text { Melanoma (post- } \\
\text { surgical resection) }\end{array}$ & Merck & CEX & NA & 2011 & Park et al. (2019) \\
\hline Lipegfilgrastim & Lonquex $^{\circledast}$ & G-CSF & Neutropenia & Teva & NA & NA & 2013 & Awwad et al., 2018 \\
\hline $\begin{array}{l}\text { Peginterferon } \\
\text { beta-1a }\end{array}$ & Plegridy ${ }^{\circledast}$ & IFN beta-1a & $\begin{array}{l}\text { Relapsing forms of } \\
\text { multiple sclerosis }\end{array}$ & Biogen & $\begin{array}{l}\text { SEC- } \\
\text { CEX }\end{array}$ & $\begin{array}{l}\text { Superose 6, SP } \\
\text { Sepharose FF }\end{array}$ & 2014 & $\begin{array}{l}\text { Pepinsky et al. (2001); } \\
\text { Pepinsky et al. (2005) }\end{array}$ \\
\hline $\begin{array}{l}\text { PEG-growth } \\
\text { hormone }\end{array}$ & Jintrolong ${ }^{\circledR}$ & $\begin{array}{l}\text { Human growth } \\
\text { hormone }\end{array}$ & $\begin{array}{l}\text { Growth hormone } \\
\text { deficiency }\end{array}$ & GeneScience & AEX & Q Sepharose & 2014 & Jin et al., 2012 \\
\hline $\begin{array}{l}\text { Rurioctocog alfa } \\
\text { pegol }\end{array}$ & Adynovate $^{\circledast}$ & $\begin{array}{l}\text { Coagulation factor } \\
\text { VIII }\end{array}$ & Hemophilia A & Shire & SEC & Superose $6 \mathrm{HR}$ & 2016 & Bossard et al. (2012) \\
\hline $\begin{array}{l}\text { Nonacog beta } \\
\text { pegol }\end{array}$ & Rebinyn $^{\circledR}$ & $\begin{array}{l}\text { Coagulation } \\
\text { factor IX }\end{array}$ & Hemophilia B & Novo Nordisk & AEX & POROS 50 HQ & 2017 & Wiendahl et al. (2020) \\
\hline $\begin{array}{l}\text { Calaspargase } \\
\text { pegol }\end{array}$ & Asparlas $^{\mathrm{TM}}$ & L-asparaginase & $\begin{array}{l}\text { Acute lymphoblastic } \\
\text { leukemia }\end{array}$ & $\begin{array}{l}\text { Servier } \\
\text { Pharmaceuticals }\end{array}$ & NA & NA & 2018 & Marini et al., 2017 \\
\hline Elapegademase & Revcovi ${ }^{\mathrm{TM}}$ & ADA & $\begin{array}{l}\text { ADA severe } \\
\text { combined } \\
\text { immunodeficiency }\end{array}$ & $\begin{array}{l}\text { Leadiant } \\
\text { Biosciences }\end{array}$ & - & - & 2018 & $\begin{array}{l}\text { Ramos-de-la-Peña } \\
\text { and Aguilar, (2020) }\end{array}$ \\
\hline $\begin{array}{l}\text { Damoctocog alfa } \\
\text { pegol }\end{array}$ & $\operatorname{Jivi}^{\circledR}$ & $\begin{array}{l}\text { Coagulation factor } \\
\text { VIII }\end{array}$ & Hemophilia A & Bayer & CEX & SP (Cytiva) & 2018 & Mei et al. (2010) \\
\hline Pegvaliase & Palynziq $^{\circledR}$ & $\begin{array}{l}\text { Phenylalananine } \\
\text { ammonia lyase }\end{array}$ & Phenylketonuria & BioMarin & - & - & 2018 & Park et al. (2019) \\
\hline $\begin{array}{l}\text { Rurioctocog alfa } \\
\text { pegol }\end{array}$ & Adynovi $^{\left({ }^{2}\right.}$ & $\begin{array}{l}\text { Coagulation factor } \\
\text { VIII }\end{array}$ & Hemophilia A & $\begin{array}{l}\text { Baxalta } \\
\text { Innovations }\end{array}$ & CEX & MacroCap SP & 2018 & Siekmann et al. (2011) \\
\hline $\begin{array}{l}\text { Pegfilgrastim } \\
\text { jmdb }\end{array}$ & FulphilaTM & G-CSF & Neutropenia & $\begin{array}{l}\text { Mylan } \\
\text { Pharmaceuticals }\end{array}$ & CEX & NA & 2018 & Hoy, (2019) \\
\hline $\begin{array}{l}\text { Pegfilgrastim } \\
\text { cbqv }\end{array}$ & Udenyca $^{\mathrm{TM}}$ & G-CSF & Neutropenia & $\begin{array}{l}\text { Coherus } \\
\text { Bioscience }\end{array}$ & NA & NA & 2018 & Park et al. (2019) \\
\hline Pegfilgrastim & $\begin{array}{l}\text { Lapelga } \\
\text { Pelgraz }^{\text {TM }}\end{array}$ & G-CSF & Neutropenia & Apotex Inc. & NA & NA & 2018 & $\begin{array}{l}\text { Zalipsky and Pasut, } \\
2020\end{array}$ \\
\hline Pegfilgrastim & Pelmeg TM & G-CSF & Neutropenia & Mundipharma & NA & NA & 2018 & $\begin{array}{l}\text { Zalipsky and Pasut, } \\
2020\end{array}$ \\
\hline $\begin{array}{l}\text { Pegfilgrastim } \\
\text { bmez }\end{array}$ & Ziextenzo $^{\mathrm{TM}}$ & G-CSF & Neutropenia & Sandoz Inc. & NA & NA & 2019 & $\begin{array}{l}\text { Zalipsky and Pasut, } \\
2020\end{array}$ \\
\hline $\begin{array}{l}\text { Turoctocog alfa } \\
\text { pegol }\end{array}$ & Esperoct $^{\circledast}$ & $\begin{array}{l}\text { Coagulation factor } \\
\text { VIII }\end{array}$ & Hemophilia A & Novo Nordisk & AEX & Source $15 Q$ & 2019 & Stennicke et al. (2013) \\
\hline $\begin{array}{l}\text { Ropeginterferon } \\
\text { alfa-2b }\end{array}$ & Besremi & IFN alfa-2b & Polycythemia vera & PharmaEssentia & CEX & $\begin{array}{l}\text { SP } \\
\text { Sepharose XL }\end{array}$ & 2019 & $\begin{array}{l}\text { Lin and Widmann, } \\
\text { (2013) }\end{array}$ \\
\hline $\begin{array}{l}\text { Pegfilgastrim } \\
\text { apgf }\end{array}$ & Nyvepria & G-CSF & Neutropenia & Pfizer & CEX & NA & 2020 & Yang et al. (2021) \\
\hline
\end{tabular}


$A D A$, adenosine deaminase; AEX, anion exchange chromatography; CEX, cation exchange chromatography; CT, chromatographic technique; FF, fast flow; G-CSF, granulocyte colony stimulating factor; GH, growth hormone; HIC, hydrophobic interaction chromatography; HP, high performance; HR, high resolution; IFN, interferon; NA, information not available; SEC, size exclusion chromatography; TNF, tumor necrosis factor. Notice that IFN alfa-2b is approved for different treatments according to dosage and presentation form.

a protein significantly alters its molecular weight and size. A simple addition of the PEG molecular weight and the protein molecular weight will give a reasonable approximation of the final molecular weight of the conjugate. However, this is not the case for the hydrodynamic radius. A single PEG molecule, when attached to a protein of the same molecular weight, will increase the hydrodynamic radius of the resulting conjugate by more than double (Fee and Van Alstine, 2004). The elution pattern of PEGylated proteins in SEC is related to molecular size rather than molecular weight (Fee, 2009). This chromatographic technique is particularly useful for the removal of low molecular weight species from the reaction mixture (i.e., excess reagents, functionalized PEG hydrolysis products or PEGylation by-products) and separation of unreacted PEG molecules from the native protein (Jevševar et al., 2010; Fee and Van Alstine, 2011). However, it is less effective for the separation of multi-PEGylated species. SEC can effectively separate two PEGylated species with $n$ and $n-1$ PEG chains, but only up to $n=3$. For multi-PEGylated species $(n>3)$, its ability to resolve PEG conjugates differing by a single PEG chain is practically null (Fee and Van Alstine, 2006; Fee and Van Alstine, 2011). Moreover, the resolving power of SEC is notoriously greater when the protein is attached to high molecular weight PEG chains (Sherman et al., 1997).

To obtain an efficient separation between the native protein and its PEGylated counterpart by SEC, a general rule of thumb is that they must have a molecular weight difference of at least twofold (Fee, 2009). For Plegridy ${ }^{\circledR}$ (a 20 kDa-PEG interferon beta-1a indicated for multiple sclerosis), the purification process after PEGylation consists of two sequential chromatography steps: SEC followed by CEX. In the SEC step, the PEGylation reaction mixture is loaded into a Superose 6 resin and results in the separation of the mono-PEGylated conjugate from the native protein (Pepinsky et al., 2001; Pepinsky et al., 2005). The nominal molecular weight of the PEG reactant $(20 \mathrm{kDa})$ and the molecular weight of interferon beta-1a $(\sim 23 \mathrm{kDa})$ are basically equal, resulting in a conjugate with doubled molecular weight compared to that of the native protein. The downstream process of Adynovate ${ }^{\circledR}$ (a $20 \mathrm{kDa}$-di-PEGylated coagulation factor VIII for hemophilia A) consists of a single SEC step, in which Superose 6 is used as a stationary phase (Bossard et al., 2012).

Hydrophobic interaction chromatography (HIC) is also used to purify PEGylated proteins. The hydrophobicity of a protein is altered by attachment of PEG chains, either increasing or decreasing it, depending on the native's protein hydrophobicity (Fee and Van Alstine, 2006). Studies have shown that the change in hydrophobicity between the native and PEGylated proteins is sufficient to separate these species (Cisneros-Ruiz et al., 2009). However, the hydrophobicity difference that allows an efficient separation by HIC among mono- and multi-PEGylated species (including positional isomers) is only large enough when the attached
PEG has a high molecular weight ( $>20 \mathrm{kDa}$ ) (Mayolo-Deloisa et al., 2012; Huang et al., 2013). Hence, HIC may not exhibit a clearly defined elution profile of mono- and multi-PEGylated species or positional isomers when small PEG molecular weight is used (Pfister and Morbidelli, 2014), holding back the use of HIC in large-scale purification of PEGylated proteins in comparison to IEX or SEC. Only in the downstream processing of Somavert ${ }^{\circledR}$ (a $5 \mathrm{kDa}$-multi-PEGylated growth hormone receptor antagonist for acromegaly), HIC is used to remove small amounts of high molecular weight cross-linked and unreacted products. In this process, a Phenyl Toyopearl column is equilibrated with $0.35 \mathrm{M}$ sodium citrate, $0.05 \mathrm{M}$ Tris $\mathrm{pH}$ 7.6, and the PEGylated protein is eluted with a six CV linear gradient from 0.35 to $0.0 \mathrm{M}$ sodium citrate. Afterwards, a desalting step using G-25 Sephadex is carried out and finally, CEX is used to separate the multi-PEGylated species (Clark et al., 1996; Olson et al., 1997). Usually, the equilibration phase in HIC is carried out at high salt concentration to expose the hydrophobic nuclei, although the optimal salt concentration to achieve protein binding will depend upon the hydrophobicity of the resin and target protein. The growth hormone receptor antagonist presents a high degree of hydrophobicity and the ligand of the resin (phenyl group) is also highly hydrophobic, therefore, mild salt conditions are required to bind the protein to the resin. Unfortunately, for many proteins mild salt conditions are not enough for binding and other salts, like ammonium sulphate, most be used at higher concentrations. This reason also accounts to the drawback for HIC implementation at large scale.

\section{Stationary Phases}

The selection of a chromatography media for large-scale purification of a protein is not trivial. There are different aspects to consider about the stationary phase, such as physicochemical properties and commercial aspects (costs and supply chain management) (Cooney, 1984). Features such as backbone matrix, ligand, particle size distribution, and pore size will determine the physical and chemical properties of the chromatographic media. To achieve a good performance in the purification of PEGylated proteins, the chromatographic resin should meet several aspects such as high hydrophilicity, good chemical and physical stability, large pore size according to the target PEGylated protein, high binding capacity and resolution, narrow particle size distribution, and avoid non-specific interactions (Huang et al., 2013).

The purification of commercial PEGylated proteins is carried out mainly using agarose-based resins, followed by polymethacrylate-based resins (Table 2). The mechanical strength of the resin is largely dependent on the material of the backbone matrix, particle size distribution, and particle porosity (Nweke et al., 2017). Agarose and methacrylate-based 
TABLE 2 | Structural properties of resins used to purify commercial PEGylated proteins. Information is based on manufacturer's data sheets unless cited otherwise.

\begin{tabular}{|c|c|c|c|c|c|c|}
\hline Stationary phase & CT & Ligand & Backbone matrix & $\begin{array}{l}\text { Particle size } \\
(\mu \mathrm{m})\end{array}$ & $\begin{array}{c}\text { Pore size } \\
\text { (nm) }\end{array}$ & Manufacturer \\
\hline Q Sepharose HP & Strong AEX & Quaternary ammonium (Q) & $6 \%$ CLA & $24-44$ & $70^{\mathrm{a}}$ & Cytiva \\
\hline Source $15 Q$ & & & Polystyrene/divinyl benzene & 15 & $20-1000^{b}$ & Cytiva \\
\hline Mono Q & & & Polystyrene/divinyl benzene & 10 & $100^{\mathrm{C}}$ & Cytiva \\
\hline POROS $50 \mathrm{HQ}$ & & Quaternized polyethyleneimine & Polystyrene/divinyl benzene & 50 & $1726^{d}$ & Thermo Scientific ${ }^{\mathrm{TM}}$ \\
\hline TSKgel SP-5PW & Strong CEX & Sulfopropyl (SP) & Polymethacrylate & 10 & 100 & Tosoh \\
\hline SP Sepharose HP & & & $6 \%$ CLA & $24-44$ & $70^{\mathrm{a}}$ & Cytiva \\
\hline SP Sepharose FF & & & $6 \%$ CLA & $45-165$ & $60^{a}$ & Cytiva \\
\hline SP Sepharose XL & & & CLA, with dextran surface extender & $45-165$ & $12^{\mathrm{e}}$ & Cytiva \\
\hline MacroCap SP & & & Acrylamide-dextran copolymer & 50 & $100^{f}$ & Cytiva \\
\hline Toyopearl CM-650S & $\begin{array}{l}\text { Weak } \\
\text { CEX }\end{array}$ & Carboxymethyl (CM) & Polymethacrylate & 35 & 100 & Tosoh \\
\hline Phenyl Toyopearl 650M & $\mathrm{HIC}$ & Phenyl & Polymethacrylate & 65 & 100 & Tosoh \\
\hline Superose 6 & SEC & - & Highly CLA & $30-40$ & $25-29^{9}$ & Cytiva \\
\hline
\end{tabular}

AEX, anion exchange chromatography; CEX, cation exchange chromatography; CLA, cross-linked agarose; CT, chromatographic technique; FF, Fast Flow; HIC, hydrophobic interaction chromatography; HP, high performance; NA, information not available; SEC, size exclusion chromatography.

${ }^{a}$ Avallin et al., 2016

${ }^{b}$ Miyabe and Guiochon, 2000

cMant and Hodges, 1991

${ }^{d}$ Yao and Lenhoff, 2006

eYao and Lenhoff, 2004

${ }^{t}$ Huang et al., 2013

gNweke et al., 2017.

matrices are often employed in ion exchangers for industrial scale purification of therapeutic proteins (Pabst et al., 2007; Liu et al., 2010). Agarose is commonly used as a backbone material because its manufacture and customization (i.e., porosity and functionalization) is relatively straightforward (Nweke et al., 2017). Additionally, the high degree of hydroxylation of this natural polymer makes it highly hydrophilic, which prevents non-specific interactions with proteins (Jungbauer, 2005). Typically, during its manufacturing agarose is cross-linked to build a more rigid structure with enhanced mechanical stability (Jungbauer, 2005; Nweke et al., 2017). Conversely, cellulose-based matrices have a macro-porous structure which can offer high binding capacities. However, this kind of matrix is not used for the purification of commercial PEGylated proteins. This may be due to the fact that in comparison to agarose-based resins, cellulose-based matrices are hard to pack, and present deficient flow performance (Levison et al., 1996; Jungbauer, 2005). In large-scale production, good flow performance is crucial since it allows to achieve shorter processing times.

On the other hand, resins based on synthetic polymers, such as polymethacrylate and polystyrene/divinylbenzene have also been used for PEGylated proteins purification (Table 2). They present several advantages over natural polymer-based resins, including resistance to extreme chemical conditions ( $\mathrm{pH}$ and oxidizing environments), greater mechanical strength, and larger pore sizes (Carta and Jungbauer, 2010). Acrylamide-dextran copolymer used in MacroCap SP resin, is another matrix worth mentioning. MacroCap SP was designed especially for the purification of PEGylated molecules at large-scale, with operating conditions at $120 \mathrm{~cm} / \mathrm{h}$, with an optimum bed height of 15-30 cm (Fee and Van Alstine, 2011; Huang et al., 2013).

\section{Particle and Pore Size}

The particle size of the resin, depending on the type of operation, impacts the chromatographic resolution and the dynamic binding capacity, and influences the pressure drop (Carta and Jungbauer, 2010). A wide range of particle sizes $(10-165 \mu \mathrm{m})$ and pore sizes $(12-1726 \mathrm{~nm})$ are used to purify commercial PEGylated proteins (Table 2). Notice that resins with small particle sizes $(\sim 30 \mu \mathrm{m})$ have a large pore size (all of them correspond to synthetic-based matrices), while resins with large particle sizes $(\sim 90 \mu \mathrm{m})$ have a small pore size (all of them correspond to agarose-based matrices). Large particles $(>50 \mu \mathrm{m})$ provide low pressure drops and ease the packing and manufacturing process compared to small particles (Jungbauer, 2005). However, when large beads and high flow rates are used, the chromatographic efficiency depends almost completely on mass transfer kinetics (Carta et al., 2005). On the contrary, small particles $(20-50 \mu \mathrm{m})$ are usually employed for large-scale purifications that require a high efficiency (Carta and Jungbauer, 2010). Beads with a narrow particle size distribution (PSD) may result in less backpressure and higher resolution (Huang et al., 2013). This is the case for resins such as Source 15Q, Mono Q and POROS $50 \mathrm{HQ}$, which were designed for fast high-resolution ion exchange protein separations.

The pore size of the resin plays an important role in mass transfer kinetics, which may be negatively affected if the pore size is either close or smaller than the target protein. To obtain fast, high-resolution separation processes, high mass transfer rates are required. This may be achieved with beads featuring highly interconnected, large pores. However, large pores may also reduce surface area, and subsequently decrease resin capacity (Jungbauer and Hahn, 2008). Since PEGylated proteins have a large molecular size, the selection of an appropriate resin pore size is of great importance. To overcome the hindered diffusion effect 
exerted by PEG chains in conventional resins with pore sizes $<100 \mathrm{~nm}$, macroporous resins have emerged as a technological solution. These resins can be operated at high flow rates without compromising efficiency and capacity (Qu et al., 2008). MacroCap SP, a macroporous resin, is used in the downstream processing of Adynovi ${ }^{\circledR}$ (indicated for hemophilia A) (Siekmann et al., 2011). By using MacroCap SP, $100 \mathrm{~nm}$ pore size, it is possible to purify the full-length coagulation factor VIII (280 kDa) linked to two $20 \mathrm{kDa}$ PEG chains (Turecek et al., 2012). Resins with a similar pore size that have been used to purify other commercial PEGylated proteins with similar or smaller molecular weights include, Mono Q, TSKgel SP-5PW, Toyopearl CM-650S and Phenyl Toyopearl 650M (see Tables 1, 2).

Perfusion chromatography media has also proven to be effective for the purification of PEGylated proteins. This type of resin overcomes problems associated with mass transfer in the separation of large molecules. It is constituted by two sets of pores: through-pores and diffusive pores, promoting a better access to the inside of the particle by the combination of convective and diffusive flow (García et al., 2000). POROS 50 $\mathrm{HQ}$, a perfusion resin, is used in the downstream processing of $98 \mathrm{kDa}$ Rebinyn ${ }^{\circledR}$ (Wiendahl et al., 2020). The large pore size of POROS $50 \mathrm{HQ}(1726 \mathrm{~nm})$ enhances mass transfer rates due to intraparticle convection and diffusion without compromising the binding capacity (Yao and Lenhoff, 2006). Matlschweiger et al. demonstrated that the binding capacity of thyroglobulin $(680 \mathrm{kDa})$ is five times larger when using POROS 50 HQ rather than Q Sepharose FF (60 nm pore size), evidencing the promising balance between transport kinetics and binding capacity of perfusion resins (Matlschweiger et al., 2019).

Sepharose XL is an agarose-based media grafted with dextran to increase exposure and density of ion-exchangers ligands, resulting in higher loading capacities than those of Sepharose FF materials (Yao and Lenhoff, 2006). As a consequence of the dextran chains filling the pores, SP Sepharose XL has a pore size of $12 \mathrm{~nm}$, five times smaller than its non-grafted analogue SP Sepharose FF. Despite its small pore size, this resin has shown to be effective for separating PEGylated proteins. This may be attributed to the presence of dextran chains, which make the adsorption sites to be flexible, enhancing the binding capacity and allowing a better resolution (Hubbuch et al., 2003; Zhu and Carta, 2014; Angelo and Lenhoff, 2016). This resin is used in the downstream processing of Besremi ${ }^{\circledR}$, an interferon alfa-2b linked to a $40 \mathrm{kDa}$-branched PEG indicated for the treatment of polycythemia vera (Lin and Widmann, 2013).

\section{Trends in Chromatographic Supports for PEGylated Proteins Purification}

Currently, there is a great number of chromatography media on the market; however, there is not a single resin that completely meets all the optimum requirements to achieve a high resolution separation. Continuous advancements in materials, polymer science, and ligand chemistry are boosting the development of more robust and versatile resins to achieve a good separation and high resolution under a broad range of experimental conditions. For instance, Zhai et al. developed gigaporous polystyrene/ divinylbenzene-based agarose-grafted particles (Agap-co-PS) with a narrow PSD $(30-85 \mu \mathrm{m})$ and vast network of interconnected through-pores and diffusive pores $(100-500 \mathrm{~nm})$. By using a sulfopropyl-modified version of these particles as chromatography media, the purification of PEGylated G-CSF (granulocyte colony stimulating factor) was improved in terms of purity and yield compared to MacroCap SP resin (Qu et al., 2008; Zhai et al., 2012). Another interesting alternative for the purification of PEGylated proteins is to use monolithic chromatographic supports. They possess highly connected open pores allowing convective mass transfer and high flow rates. The ability of monoliths to separate PEGylated proteins by IEX and HIC modes has been demonstrated in previous reports (Gašperšič et al., 2016; Mayolo-Deloisa et al., 2016).

The modification of chromatography media with novel ligands has also been investigated as a strategy to improve PEGylated proteins purification. Different chromatographic supports have been grafted with PEG molecules of varying molecular weights to improve resolution and even separate positional isomers of mono-PEGylated species by exploiting the called "hydrophobicity-shielding effect" (HernándezMartínez and Aguilar, 2014; Sánchez-Trasviña et al., 2019). Heparin has also been proposed as a novel ligand to separate PEGylated proteins by affinity chromatography. Mejía-Manzano et al. used Heparin Sepharose 6 FF to purify PEGylated lysozyme through a $\mathrm{NaCl}$ step gradient reaching a $100 \%$ of yield and purity (Mejía-Manzano et al., 2017).

Process integration is a trend in biopharmaceutical production used to diminish costs and manufacturing times. In this context, on-column PEGylation has emerged as a strategy to merge the PEGylation reaction, separation, and purification in a single step. Furthermore, on-column PEGylation may result in a more homogeneous mixture of PEG conjugates. This methodology can be applied practically with all chromatography modes, but it has been extensively explored with IEX in recent years (Maiser et al., 2015; Pfister et al., 2016; Wang et al., 2017). The next step forward is to switch from a batch-mode on-column PEGylation to a continuous process. Ingold et al. demonstrated that by implementing a reactive multicolumn countercurrent solvent gradient purification (rMCSGP) process, it was possible to obtain mono-PEGylated alpha-lactalbumin with a higher yield (85\%) and productivity compared to batch on-column PEGylation (Ingold et al., 2016).

\section{FC-FUSION}

Fc-fusion proteins are composed of an immunoglobulin Fc domain that is genetically fused to a protein of interest, such as a protein domain, enzyme, ligand or peptide (Yang et al., 2018). If a single protein molecule is bonded to the Fc domain (which consist of a dimeric form of $\mathrm{CH} 2-\mathrm{CH} 3$ domain), the Fc-fusion protein is said to be monomeric, whereas dimeric Fc-fusion proteins consist of two protein molecules fused to the Fc domain, resembling the structure of natural immunoglobulins (Rath et al., 2015). The Fc domain confers new biological and 
TABLE 3 | Approved Fc-fusion proteins.

\begin{tabular}{|c|c|c|c|c|c|c|c|c|}
\hline $\begin{array}{l}\text { International } \\
\text { non- } \\
\text { proprietary } \\
\text { name }\end{array}$ & $\begin{array}{l}\text { Brand } \\
\text { name }\end{array}$ & Protein & Treatment & Company & CTS & $\begin{array}{c}\text { Stationary } \\
\text { phase }\end{array}$ & $\begin{array}{l}\text { Approval } \\
\text { year }\end{array}$ & References \\
\hline Etanercept & Enbrel $^{\circledast}$ & $\begin{array}{l}\text { p75 TNF } \\
\text { receptor (ED) }\end{array}$ & $\begin{array}{l}\text { Rheumatoid arthritis, } \\
\text { autoimmune and } \\
\text { inflammatory diseases }\end{array}$ & Boehringer/Pfizer & $\begin{array}{l}\text { AF- } \\
\text { IEX-NA }\end{array}$ & NA & 1998 & $\begin{array}{l}\text { Hassett et al. } \\
\text { (2018); Mohler } \\
\text { et al. (1993) }\end{array}$ \\
\hline Abatacept & Orencia $^{\circledR}$ & CTLA-4 (ED) & Rheumatoid arthritis & $\begin{array}{l}\text { Lonza/Bristol- } \\
\text { Myers }\end{array}$ & $\begin{array}{l}\text { AF-NA- } \\
\text { NA-NA }\end{array}$ & NA & 2005 & $\begin{array}{l}\text { Linsley et al. } \\
\text { (1998) }\end{array}$ \\
\hline Rilonacept & Arcalyst $^{\circledast}$ & $\begin{array}{l}\text { IL-1R accessory } \\
\text { protein }\end{array}$ & $\begin{array}{l}\text { Cryopyrin-associated } \\
\text { periodic syndromes }\end{array}$ & $\begin{array}{l}\text { Regeneron } \\
\text { Pharmaceuticals }\end{array}$ & $\begin{array}{l}\text { AF- } \\
\text { SEC }\end{array}$ & NA & 2008 & $\begin{array}{l}\text { Economides } \\
\text { et al. (2003) }\end{array}$ \\
\hline Romiplostim & NPlate ${ }^{\circledast}$ & $\begin{array}{l}\text { Thrombopoietin } \\
\text { receptor agonist }\end{array}$ & $\begin{array}{l}\text { Thrombocytopenia in } \\
\text { chronic immune } \\
\text { thrombocytopenic } \\
\text { purpura patients }\end{array}$ & Amgen/Pfizer & $\begin{array}{l}\text { CEX- } \\
\text { CEX }\end{array}$ & $\begin{array}{l}\text { SP Sepharose FF- } \\
\text { SP Sepharose HP }\end{array}$ & 2008 & Liu et al. (2017) \\
\hline Aflibercept & Eylea $^{\circledR}$ & $\begin{array}{l}\text { VEGF receptors } 1 \\
\text { and } 2(\mathrm{BD})\end{array}$ & $\begin{array}{l}\text { Wet age-related macular } \\
\text { degeneration, diabetic } \\
\text { macular edema }\end{array}$ & $\begin{array}{l}\text { Regeneron } \\
\text { Pharmaceuticals }\end{array}$ & $\begin{array}{l}\text { AF- } \\
\text { CEX- } \\
\text { AEX- } \\
\text { HIC }\end{array}$ & NA & 2011 & $\begin{array}{l}\text { Assadourian } \\
\text { et al. (2014) }\end{array}$ \\
\hline Belatacept & Nulojix ${ }^{\circledR}$ & CTLA-4 (ED) & Organ rejection & Bristol-Myers & $\begin{array}{l}\text { AF- } \\
\text { AEX- } \\
\text { HIC }\end{array}$ & $\begin{array}{l}\text { MabSelect Protein } \\
\text { A, Q Sepharose FF, } \\
\text { Toyopearl Phenyl } \\
650 \mathrm{M}\end{array}$ & 2011 & $\begin{array}{l}\text { Leister et al. } \\
\text { (2010) }\end{array}$ \\
\hline Alefacept & Amevive $^{\circledR}$ & LFA-3 (ED) & $\begin{array}{l}\text { Psoriasis and organ } \\
\text { rejection }\end{array}$ & Astellas Pharma & $\begin{array}{l}\text { AF- } \\
\text { SEC }\end{array}$ & $\begin{array}{l}\text { Protein } \\
\text { A-Sepharose 4B, } \\
\text { Superose } 12\end{array}$ & 2011 & $\begin{array}{l}\text { Miller et al. } \\
\text { (1993); Wallner } \\
\text { et al. (1999) }\end{array}$ \\
\hline Ziv-aflibercept & Zaltrap $^{\circledR}$ & $\begin{array}{l}\text { VEGF receptors } 1 \\
\text { and } 2(\mathrm{BD})\end{array}$ & $\begin{array}{l}\text { Metastatic colorectal } \\
\text { cancer }\end{array}$ & $\begin{array}{l}\text { Regeneron } \\
\text { Pharmaceuticals }\end{array}$ & $\begin{array}{l}\text { AF- } \\
\text { CEX- } \\
\text { AEX- } \\
\text { HIC }\end{array}$ & NA & 2012 & $\begin{array}{l}\text { Assadourian } \\
\text { et al. (2014) }\end{array}$ \\
\hline $\begin{array}{l}\text { Efmoroctocog } \\
\text { alfa }\end{array}$ & Eloctate $^{\circledR}$ & $\begin{array}{l}\text { Coagulation factor } \\
\text { VIII (B-domain } \\
\text { deleted) }\end{array}$ & Hemophilia A & Biogen & $\begin{array}{l}\text { AF- } \\
\text { AEX- } \\
\text { HIC }\end{array}$ & $\begin{array}{l}\text { VIIISelect, Fractogel } \\
\text { EMD TMAE Hicap, } \\
\text { Octyl Sepharose } \\
4 \text { FF }\end{array}$ & 2014 & $\begin{array}{l}\text { Dumont et al. } \\
\text { (2012); McCue } \\
\text { et al. (2015) }\end{array}$ \\
\hline $\begin{array}{l}\text { Eftrenonacog } \\
\text { alfa }\end{array}$ & Alprolix ${ }^{(3)}$ & $\begin{array}{l}\text { Coagulation } \\
\text { factor IX }\end{array}$ & Hemophilia B & Biogen & $\begin{array}{l}\text { AF- } \\
\text { AEX- } \\
\text { AEX }\end{array}$ & $\begin{array}{l}\text { MabSelect SuRe, } \\
\text { Fractogel DEAE, Q } \\
\text { Sepharose }\end{array}$ & 2014 & $\begin{array}{l}\text { McCue et al. } \\
\text { (2014); Peters } \\
\text { et al. (2010) }\end{array}$ \\
\hline Dulaglutide & Trulicity $^{\circledR}$ & $\begin{array}{l}\text { GLP-1 receptor } \\
\text { agonist }\end{array}$ & $\begin{array}{l}\text { Glycemic control in type } 2 \\
\text { diabetes mellitus }\end{array}$ & Eli Lilly and Co. & $\begin{array}{l}\text { AF- } \\
\text { SEC }\end{array}$ & $\begin{array}{l}\text { Protein A } \\
\text { Sepharose HP, } \\
\text { Superdex } 200\end{array}$ & 2014 & $\begin{array}{l}\text { Glaesner et al. } \\
(2010)\end{array}$ \\
\hline $\begin{array}{l}\text { Luspatercept- } \\
\text { aamt }\end{array}$ & Reblozyl $^{\circledast}$ & $\begin{array}{l}\text { Activin receptor } \\
\text { Type IIB } \\
\text { (Modified ED) }\end{array}$ & $\begin{array}{l}\text { Anemia in adult with beta } \\
\text { thalassemia }\end{array}$ & $\begin{array}{l}\text { Celgene Corp/ } \\
\text { Acceleron } \\
\text { Pharma Inc. }\end{array}$ & $\begin{array}{l}\text { AF- } \\
\text { AEX }\end{array}$ & $\begin{array}{l}\text { MabSelect SuRe, } \\
\text { Q-Sepharose }\end{array}$ & 2019 & $\begin{array}{l}\text { Sako et al. } \\
(2010)\end{array}$ \\
\hline
\end{tabular}

AEX, anion exchange chromatography; $A F$, affinity chromatography; $B D$, binding domain; CEX, cation exchange chromatography; CTLA-4, cytotoxic lymphocyte-associated antigen 4; CTS, chromatographic techniques sequence; ED, extracellular domain; GLP-1, glucagon-like peptide-1; HIC, hydrophobic interaction chromatography; IL-1, interleukin-1; LFA-3, leukocyte function antigen-3; NA, information not available; SEC, size exclusion chromatography; TNF, tumor necrosis factor; VEGF, vascular endothelial growth factor.

pharmacological properties to the protein, such as extended circulation half-life, enhanced solubility and stability, and modulated immunogenicity, and enhanced Fc-mediated effector functions (Czajkowsky et al., 2012; Yang et al., 2018). Although there are several types of immunoglobulins, IgG is the most used for constructing Fc-fusion proteins, probably because it has the longest circulation half-life (Jazayeri and Carroll, 2008). At present, twelve Fc-fusion proteins have obtained regulatory approval and are available on the market (Table 3).

Fc-fusion proteins are produced by genetic engineering using a wide variety of expression systems. Mammalian systems are often preferred because they maintain proper folding of the protein, are able to perform post-translational modifications, and they allow easy extracellular secretion of the protein, which simplifies the downstream process (Jazayeri and Carroll, 2008). Among commercial Fc-fusion proteins, only NPlate ${ }^{\circledR}$ (a thrombopoietin receptor agonist to treat thrombocytopenia) is produced in a prokaryotic system. In addition to the impurities related to the recombinant production of $\mathrm{Fc}$-fusion proteins, such as host cell proteins (HCP), virus, and DNA, several other contaminants are generated (Shukla and Gottschalk, 2013); for instance, one problem often encountered with Fc-fusion proteins is the formation of high molecular weight aggregates (HMWA) (Vaniotis et al., 2018). Also, low molecular weight species (LMWs), which include an incomplete Fc domain, may be produced (Zhu et al., 2019). To ensure safety and efficacy of the final product, it is critical to have a robust downstream process 


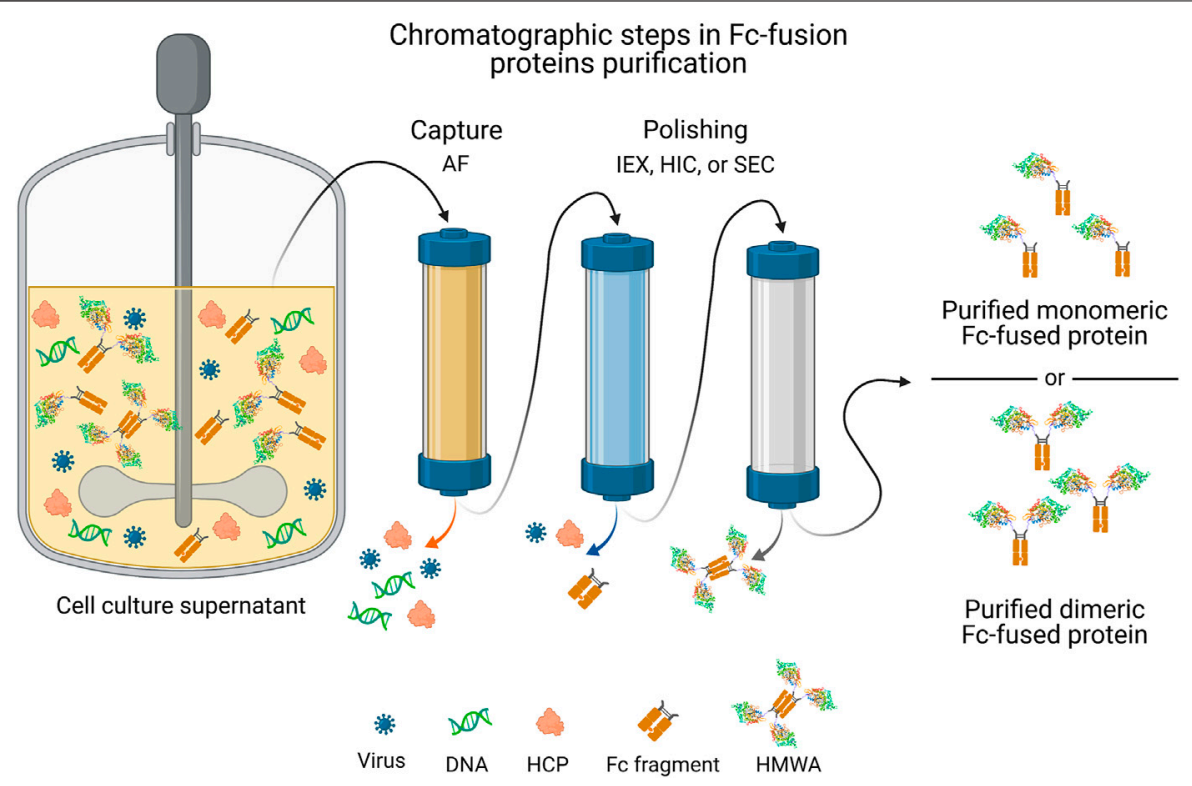

FIGURE 3 | General strategy of chromatographic steps in the purification process of commercial Fc-fusion proteins produced in mammalian cells culture. A single capture step is followed by two polishing steps that involve a combination of chromatographic operational modes to obtain the purified monomeric or dimeric Fc-fusion protein. AF, affinity chromatography; HCP, host cell proteins; HIC, hydrophobic interaction chromatography; HMWA, high molecular weight aggregates; IEX, ion exchange chromatography; SEC, size exclusion chromatography. Fc-fusion protein structures are merely representative, the current structure for each Fc-fusion protein may vary.

that maximizes the removal of process and product-related impurities.

Given the structural resemblance between Fc-fusion proteins and monoclonal antibodies (mAbs), the purification approaches employed for the latter may serve as a base platform to purify Fcfusion proteins. However, biochemical properties (i.e., $\mathrm{pH}-$ sensitivity, pI, and aggregation-propensity) between these molecules substantially differ, requiring specific adjustments in the downstream process for Fc-fusion proteins (Shukla and Norman, 2017). The general scheme of the purification process for mammalian system-expressed Fc-fusion proteins (Figure 3) involves: i) a capture step, which aims to eliminate most HCP, DNA, and other cell culture-related impurities; ii) an intermediate step for viral inactivation; and iii) a polishing step, oriented to remove any remaining impurities and HMWA (Shukla and Thömmes, 2010). It is important to highlight that the structure of Fc-fusion proteins may vary (Duivelshof et al., 2021). The downstream processing for Fc-fusion proteins typically includes three chromatographic steps, often an affinity chromatography for capture, and two different chromatographic techniques (IEX, HIC or SEC) for polishing.

\section{Capture Step}

Most commercial Fc-fusion proteins use protein A affinity chromatography as an initial capture step in their downstream processing, except for Nplate ${ }^{\circledR}$ and Eloctate ${ }^{\circledR}$ (a B domain-deleted coagulation factor VIII for hemophilia A) (Table 3). This technique relies on the highly specific interaction between the Fc domain of antibodies with protein A ligand. A single step of protein A chromatography may result in $>98 \%$ purity even with complex cell culture media as a starting material (Shukla et al., 2007). Protein A chromatography is effective in removing process-related contaminants such as HCP, DNA, and virus, relieving the burden on subsequent intermediate and polishing steps (Pinto et al., 2015).

Regardless of its advantages, protein A chromatography faces some issues related to $\mathrm{pH}$ sensitivity of $\mathrm{Fc}$-fusion proteins. Generally, the protein binds to the column at neutral $\mathrm{pH}$, and elutes at acidic pH (Ghose et al., 2006; Jazayeri and Carroll, 2008). Low $\mathrm{pH}$ values may negatively impact the integrity and biological activity of Fc-fusion proteins, or promote the formation of HMWA (Shukla et al., 2007). Product aggregation may be prevented by addition of stabilizers, such as arginine or glycine into the elution buffer (Arakawa et al., 2004). Whereas the use of chaotropic salts, such as urea, or guanidine hydrochloride may be utilized as "disaggregation" agents to dissociate HMWA and recover functional monomers (Xu et al., 2010).

Several other limitations can also be pointed out regarding protein A chromatography, including resin cost, throughput, and resin instability (Fahrner et al., 1999; Follman and Fahrner, 2004). A wide variety of Protein A resins are commercially available. However, costs between $\$ 8,000-15,000$ USD per liter for this type of resins translate into higher expenses compared to traditional resins using non-protein-based ligands (Ramos-de-la-Peña et al., 2019). Furthermore, due to the high cost of the resin, typical bioprocesses rely on running several cycles of short-column Protein A chromatography steps to purify a single batch of product, increasing total purification time and decreasing production rate (Ghose et al., 2007). This results in multiple 
TABLE 4 | Structural properties of resins used to purify commercial Fc-fusion proteins. Information is based on manufacturer's data sheets unless cited otherwise.

\begin{tabular}{|c|c|c|c|c|c|c|}
\hline Stationary phase & CT & Ligand & Backbone matrix & $\begin{array}{l}\text { Particle size } \\
\qquad(\mu \mathrm{m})\end{array}$ & $\begin{array}{c}\text { Pore size } \\
\text { (nm) }\end{array}$ & Manufacturer \\
\hline Q Sepharose HP & Strong AEX & Quaternary ammonium (Q) & $6 \%$ CLA & $24-44$ & $70^{a}$ & Cytiva \\
\hline Q Sepharose FF & & & $6 \%$ CLA & $45-165$ & $60^{\mathrm{a}}$ & Cytiva \\
\hline Fractogel EMD TMAE HiCap & & Trimethylammoniumethyl (TMAE) & Polymethacrylate & 40-90 & 80 & MerckMillipore \\
\hline Fractogel EMD DEAE & Weak AEX & Diethylaminoethyl (DEAE) & Polymethacrylate & 40-90 & 80 & MerckMillipore \\
\hline SP Sepharose HP & Strong CEX & Sulfopropyl (SP) & $6 \%$ CLA & $24-44$ & $70^{a}$ & Cytiva \\
\hline SP Sepharose FF & & & & $45-165$ & $60^{a}$ & Cytiva \\
\hline Phenyl Toyopearl 650M & $\mathrm{HIC}$ & Phenyl & Polymethacrylate & 65 & 100 & Tosoh \\
\hline Octyl Sepharose 4 FF & & Octyl & $4 \%$ CLA & $45-165$ & $110^{\mathrm{a}}$ & Cytiva \\
\hline MabSelect Protein A & $\mathrm{AF}$ & Recombinant protein A (E. coli) & Highly CLA & $40-130$ & $120^{\mathrm{a}}$ & Cytiva \\
\hline Protein A Sepharose HP & & Protein A & $6 \%$ CLA & $24-44$ & $70^{\mathrm{a}}$ & Cytiva \\
\hline MabSelect SuRe & & Alkali-stabilized Protein A-derived (E. coll) & Highly CLA & 85 & $120^{\mathrm{a}}$ & Cytiva \\
\hline Protein A Sepharose 4B & & Native protein A & $4 \%$ CLA & $45-165$ & $110^{\mathrm{a}}$ & Cytiva \\
\hline VIII Select & & 13 kDa recombinant protein (S.cerevisae) & Highly CLA & 75 & NA & Cytiva \\
\hline Superose 12 & SEC & - & Highly CLA & $30-40$ & $10-14^{b}$ & Cytiva \\
\hline Superdex 200 & & - & CLA and dextran & 34 & $13^{\mathrm{b}}$ & Cytiva \\
\hline
\end{tabular}

AEX, anion exchange chromatography; CEX, cation exchange chromatography; CLA, cross-linked agarose; CT, chromatographic technique; FF, fast Flow; HIC, hydrophobic interaction chromatography; HP, high performance; NA, information not available; SEC, size exclusion chromatography.

${ }^{a}$ Avallin et al., 2016

${ }^{b}$ Hagel et al., 1996.

cleaning, sanitization, and resin regeneration cycles, involving harsh acidic and alkaline conditions, which can modify Protein A three-dimensional structure and/or lead to ligand leaching (Jiang et al., 2009). The acidic environment during elution also shortens resin's lifespan. To overcome these drawbacks manufacturers have continuously engaged in the design of novel resins with improved characteristics. MabSelect SuRe ${ }^{\mathrm{TM}}$, used in the capture step of Reblozyl ${ }^{\circledR}$ (activin receptor type IIB to treat beta thalassemia) and Alprolix ${ }^{\circledR}$ (a coagulation factor IX for hemophilia B), is a resin functionalized with a tetrameric chains of alkali-stabilized protein A-derived ligand (of the Z-domain of staphycoccal protein A) produced in E. coli (Silva et al., 2018). This ligand is $\mathrm{NaOH}$ tolerant, allowing a deep cleaning of the resin after each purification round, minimizing cross-contamination, and extending the lifetime of the resin. Hahn et al. found that Protein A leaching in MabSelect $\mathrm{SuRe}^{\mathrm{TM}}$ remained at low levels $(<3 \mathrm{ppm})$ over 50 purification and cleaning (using $500 \mathrm{mM} \mathrm{NaOH}$ ) cycles, while product recovery and purity remained constant (Hahn et al., 2006). Moreover, by optimizing the cleaning and resin regeneration protocols, the lifetime of MabSelect SuRe ${ }^{\mathrm{TM}}$ could be prolonged up to 150 cycles, which may translate into economical savings in large-scale production (Zhou et al., 2019). Recently, new resin with protein A ligand designed by protein engineering (MabSelect $^{\mathrm{TM}}$ PrismA) showed greater stability for regeneration process (Wetterhall et al., 2021), however, this chromatographic material has not been reported to purify Fcfusion proteins.

Currently, a great number of commercial protein A resins with differences in the nature of the ligand (native or recombinant), valency (which dictates the Fc-fusion protein-protein A stoichiometry) and features (backbone structure, particle, and pore size distribution) are available. Most of the resins employed in the capture step of commercial Fc-fusion proteins possess similar structural properties: same backbone structure (cross- linked agarose), similar particle size $(\sim 85 \mu \mathrm{m})$ and pore size $(\sim 120 \mathrm{~nm})$ (Table 4). These features provide high surface area, large sample load, and low back pressure which are required during the capture step. Highly cross-linked agarose media can manage high flow rates, making it suitable for large-scale applications (Hahn et al., 2003; Ghose et al., 2007). Moreover, large pore sizes allow a better diffusion of modified proteins that have a molecular weight in the range between 72 and $220 \mathrm{kDa}$. Among the protein A resins utilized in the capture step of commercial Fc-fusion proteins, only one has a small pore and particle size: Protein A Sepharose HP, used for Trulicity ${ }^{\circledR}$. Trulicity $^{\circledR}$ is a glucagon-like peptide-1 (GLP-1) receptor agonist used for glycemic control in type 2 diabetes mellitus that has a molecular weight of $63 \mathrm{kDa}$. The pore size of Protein A Sepharose HP $(70 \mathrm{~nm})$ is large enough to enable protein diffusion through the pores. Additionally, the small particle size $(34 \mu \mathrm{m})$ of this resin enhances peak resolution, facilitating subsequent purification steps.

Besides protein A, other ligands may be utilized for the recovery of Fc-fusion proteins. Particularly, in the capture step of the downstream processing of Eloctate ${ }^{\circledR}$ (a beta-domain deleted coagulation factor VIII), VIIISelect resin is employed. The ligand of this resin is a Camelidae-derived $13 \mathrm{kDa}$ recombinant nanobody produced in Saccharomyces cerevisiae, which binds specifically to beta-domain-deleted factor VIII molecules (Dumont et al., 2012; McCue et al., 2015). The use of VIIISelect allows the product to be eluted at neutral $\mathrm{pH}$ conditions, which may help maintain protein integrity (McCue et al., 2015).

An exception is observed in the downstream process of Nplate $^{\circledR}$, since it does not include a capture step per se. Nplate $^{\circledR}$ is expressed as inclusion bodies in E. coli, where proteins can reach up to $90 \%$ purity. Prior to chromatography steps, inclusion bodies are recovered, solubilized, and incubated in an appropriate buffer to promote protein refolding and 
dimerization of the monomer subunits through the correct formation of disulfide bridges (Alibolandi and Mirzahoseini, 2011; Liu et al., 2017). After clarification of the refolding reaction mixture, polishing chromatography steps are employed to remove misfolded proteins, along with HMWA, and HCP (Shukla and Norman, 2017).

\section{Polishing Step}

Following capture of Fc-fusion proteins, one or two additional chromatography steps are usually employed as polishing steps. While protein A chromatography is a straightforward choice for the capture step of Fc-fusion proteins, the selection of the chromatographic techniques and sequence of polishing steps directly depends on the remaining product and impurities to be removed (Pinto et al., 2015). Polishing steps are used to remove misfolded proteins, remaining HCP, DNA, LMW, HMWA, viral particles, and leached Protein A (Shukla et al., 2007; Shukla and Norman, 2017). In addition, to achieve enough viral inactivation, an acid hold step is introduced post protein A chromatography (Shukla and Aranha, 2015). However, the duration of this step must be carefully determined, as Fc-fusion products may suffer detrimental effects if held in low $\mathrm{pH}$ environments for too long. After viral inactivation, the product pool must be neutralized before the next polishing step. In some occasions, this $\mathrm{pH}$ adjustment step may aid to remove some HCP by precipitation, however it can also sacrifice product yield (Li, 2017). To avoid some of the risks associated with a low-pH environment, solvents or detergents may also be used for viral inactivation (Conley et al., 2017).

For most commercial Fc-fusion proteins, IEX predominates as a first polishing step (Table 3). This inexpensive and rapid chromatographic technique allows to remove HCP, DNA, viral particles, leached protein A, and charge variants (Liu et al., 2010). Since most Fc-fusion proteins have a pI less than 7, AEX in a bind-elute mode is a great choice for removing impurities (Shukla and Gottschalk, 2013). The product pool is first loaded onto the anion exchange column and the protein is then eluted by a salt or $\mathrm{pH}$ gradient. Acidic impurities, such as DNA, HCP, and viral particles also bind to the resin, and are eluted during cleaning or regeneration steps (Liu et al., 2010). AEX has also been employed in a weak partitioning mode. In this operation mode, $\mathrm{pH}$ and ionic strength are selected to enhance binding of the protein and impurities to the resin. Since impurities are more acidic than the protein they bind tightly to the resin, which leads to an increase in impurity removing performance (Liu et al., 2010; Li, 2017). AEX operated in a weak partitioning mode has proven to improve HCP and HMWA removal (Shukla and Gottschalk, 2013; Shukla et al., 2017). CEX can also be applied for the purification of Fcfusion proteins, specifically for those with $\mathrm{pI}$ values ranging from neutral to basic. This technique is typically operated in a bindelute mode. In contrast to AEX, acidic impurities do not bind to the resin since they are negatively charged and thus, are removed in the load and wash fraction (Liu et al., 2010).

After the first polishing step, a second or third step may be incorporated depending on remaining impurities and product characteristics. AEX in flow-through mode may be used if HCP and HMWA have reached satisfactory levels and the remaining impurity is DNA (Shukla and Gottschalk, 2013). Another alternative for subsequent polishing steps is using HIC. This chromatographic technique is incorporated as the last polishing step of the purification processes of Eloctate $^{\circledR}$, Zaltrap ${ }^{\circledR}$ (a vascular endothelial growth factor for metastatic colorectal cancer), Eylea ${ }^{\circledR}$ (a vascular endothelial growth factor to treat age-related macular degeneration), and Nulojix ${ }^{\circledR}$ (a cytotoxic lymphocyte-associated antigen 4 for organ rejection). HIC is often used to remove HMWA since it exploits hydrophobic interactions between aggregates and the resin (Shukla et al., 2017; Shukla and Norman, 2017). It is typically operated in a flow-through mode due to low binding capacity of HIC resins (Shukla and Gottschalk, 2013). Bind-elute protocols have also proven to be effective. For instance, HIC is used in a bind-elute mode in the downstream processing of Nulojix ${ }^{\circledR}$. The eluate from the previous AEX step is loaded onto a HIC column in a $50 \mathrm{mM}$ HEPES buffer $\mathrm{pH} 7.0$ and $3.6 \mathrm{M}$ ammonium sulfate (AS). Then, weakly bound impurities are removed through a washing step using a concentration of 1.2 M AS. Finally, the target Fc-fusion protein is eluted at $0.55 \mathrm{M}$, while HMWA remain bound to the resin (Leister et al., 2010).

Lastly, SEC is also used as a polishing step, although to a lesser extent than AEX or CEX. This chromatographic technique is employed in the downstream processing of Arcalyst $^{\circledR}$ (an Interleukin-1 accessory protein for cryopyrinassociated periodic syndromes), Amevive ${ }^{\circledR}$ (a leukocyte function antigen-3 for psoriasis and organ rejection) and Trulicity ${ }^{\circledR}$ (Table 3). SEC allows to effectively separate HMWA, Fc fragments and reduce HCP from the desired product, and at the same time helps to desalt the Fc-fusion protein solution. Due to the low load capacity of SEC columns, this chromatographic technique is typically used as the final stage of the purification process (Baumann and Hubbuch, 2017; Schmitt et al., 2017). To obtain high purity levels, a high chromatographic resolution is required, which may be achieved by using resins with small and uniform particle size (Cytiva, 2010). From Table 4, it is remarkable that SEC resins used in the downstream processes of commercial Fc-fusion proteins possess small particle size distributions $(30-40 \mu \mathrm{m})$ and small pore sizes $(10-14 \mathrm{~nm})$.

An interesting polishing scheme is observed for Alprolix ${ }^{\circledR}$, which involves two sequential AEX steps, instead of two orthogonally different chromatographic techniques. The second AEX step is operated in a pseudo-affinity mode with the objective of recovering recombinant coagulation factor IX (Peters et al., 2010; McCue et al., 2014). Pseudo-affinity chromatography originated based on the observations that calcium ions could induce conformational changes in some proteins, modifying their hydrophobicity and/or surface charge. These changes affect the normal interaction of a protein towards conventional IEX or HIC supports (Yan, 1996). Fischer et al. observed that implementing an AEX step followed by an AEX run in pseudo-affinity mode allowed a 4 -fold increase in recombinant coagulation factor IX specific activity compared to a single AEX polishing step (Fischer et al., 1995). 


\section{Trends in Fc-Fusion Purification Strategies} Since downstream processing represents the bottleneck of biopharmaceuticals manufacturing in general, there is a continuous interest in improving the performance of chromatographic resins. In recent years, mixed-mode chromatography (MMC) has gained attention as a chromatographic technique for polishing steps and even as a substitute of protein A affinity chromatography in capture steps. Mixed-mode resins are unique stationary phases as their ligands are capable of simultaneously establishing different types of interactions with biomolecules, i.e., electrostatic, hydrophobic, and to some extent hydrogen bonding (Chu et al., 2018). MMC has been effective for clearance of HCP, DNA, leached protein A, and even HMWA. When the target Fc-fusion protein is highly sensitive to low $\mathrm{pH}$ values to use protein A chromatography, MMC can be used as a capture step instead, since protein elution is accomplished at less acidic conditions ( $\mathrm{pH} \sim 4.0$ ) (Shukla and Gottschalk, 2013). Several commercial MMC resins have been explored as protein A chromatography alternatives for the capture of Fc-fusion proteins, including MEP HyperCel, HEA HyperCel, PPA HyperCel, Capto MMC and Capto adhere. These resins have shown good product recovery and HCP clearance (Pezzini et al., 2011; Toueille et al., 2011; Joucla et al., 2013; Shukla and Gottschalk, 2013; Kaleas et al., 2014).

The implementation of MMC may also lead to the simplification of downstream processing of Fc-fusion proteins by reducing the number of chromatographic steps, which results in cost savings and improvement of process efficiency (Rathore et al., 2018). By using MMC as the sole polishing step instead of CEX followed by AEX; Herzer et al. were able to simplify the purification process of a domain antibody fragment-Fc fusion, achieving the required HCP clearance $(<100 \mathrm{ppm})$ and purity (Herzer et al., 2015). In this context, a single MMC step was able to replace two IEX polishing steps.

Ceramic hydroxyapatite (CHT) is an archetype of MMC that combines cation exchange and metal affinity. It has positively charged calcium and negatively charged phosphate groups that bind proteins via carboxyl clusters and cationic exchange (Premsukh et al., 2011). In the downstream processing of antibodies, CHT has demonstrated a superior ability to reduce antibody aggregates and HCP (Li, 2017). When CHT is used in polishing steps, relatively mild elution conditions, such as phosphate gradients $(10-500 \mathrm{mM})$ at neutral $\mathrm{pH}$ are required (Gagnon, 2009).

Lastly, increasing throughput in downstream processing of biopharmaceuticals is an urgent need in the industry. The implementation of membrane chromatography in Fc-fusion proteins manufacturing has become a feasible option to address this issue. Membrane adsorbers feature larger pore sizes than chromatographic resins. Hence, mass transfer faces less resistance as convection predominates over solute diffusion, allowing membranes to be operated at high flow rates under high loading conditions, and shortening the processing cycle (Shukla and Norman, 2017). However, as a consequence of large pore size there is a decrease in surface area, which translates into poor protein binding capacities compared to packed-bed chromatography (Gagnon, 2012). Due to this limitation, membrane adsorbers are often employed in flow-through mode. IEX-based membrane chromatography has been explored as an intermediate polishing step in $\mathrm{mAb}$ and $\mathrm{Fc}$ fusion proteins production, as it contributes to clearance of large impurities such as host DNA and viral particles (Liu et al., 2013; Orr et al., 2013). Moreover, when IEX based membrane is applied as a pre-filtration method, it may improve parvovirus filtration (Brown et al., 2010). Precisely this strategy is followed in the downstream processing of Eloctate $^{\circledR}$, where Mustang Q (an AEX-membrane adsorber) is employed after an AEX chromatography step and prior to virus filtration. In addition to its high throughput, membrane chromatography also possesses an advantage from an economical perspective. Membrane adsorbers are inexpensive and usually commercialized in single-use, disposable formats, which may diminish costs and time required for validation and routine implementation of cleaning and regeneration protocols of multi-use chromatography resins (Hou et al., 2015).

\section{LIPIDATION}

Lipidation, a natural process that takes place in eukaryotic cells, is a post translational modification in which a lipid moiety is covalently attached to a protein. Among the lipid molecules used for protein modification are long-chain fatty acyl groups, isoprenoids, sterols, phospholipids, lipid-derived electrophiles, and glycosylphosphatidylinositol, which are conjugated to proteins in cells by specific transferases (Resh, 2013; Chen et al., 2018). Typically, conjugation to fatty acyl groups (acylation) or isoprenoids occurs at nucleophilic side chains (mainly cysteine, serine and lysine residues) or the $\mathrm{N}$-terminus of proteins, while modification with cholesterol or glycosylphosphatidylinositol occurs at the C-terminus (Jiang et al., 2018).

Lipidation of therapeutic proteins is mainly carried out through $\mathrm{N}$-acylation with long-chain fatty acids, as a strategy to improve the biomolecule stability and circulation half-life (Longo et al., 2014). Half-life extension is given by the noncovalent interaction between the fatty acid moiety and human serum albumin (HSA), one of the most abundant proteins in plasma, which has a half-life of several weeks (Knudsen and Lau, 2019). Once the fatty acid moiety of the lipidated protein binds to HSA, the lipidated protein is protected from proteolytic degradation and renal clearance (Dalbøge et al., 2015). Furthermore, lipidated proteins have shown to self-assemble into oligomeric complexes, especially in the presence of zinc ions. These complexes are less susceptible to proteolytic degradation, and work as a prolonged release mechanism, since drug monomers gradually dissociate from the complex (Havelund et al., 2004; Jonassen et al., 2012; van Witteloostuijn et al., 2016).

Lipidation, as a half-life extension strategy, has been primarily implemented for small proteins and peptides. During the modification process, the hydrophobicity of the native protein is increased by the attachment of a fatty acid chain. This effect is greater in small proteins and peptides in comparison to larger 
TABLE 5 | Approved proteins with other modifications: albumin-fusion, glycosylation, and lipidation.

\begin{tabular}{|c|c|c|c|c|c|c|c|c|c|}
\hline Modification & $\begin{array}{c}\text { International } \\
\text { non-proprietary } \\
\text { name }\end{array}$ & $\begin{array}{l}\text { Brand } \\
\text { name }\end{array}$ & Protein & Treatment & Company & CTS & $\begin{array}{l}\text { Stationary } \\
\text { phase }\end{array}$ & $\begin{array}{l}\text { Approval } \\
\text { year }\end{array}$ & References \\
\hline $\begin{array}{l}\text { Albumin- } \\
\text { fusion }\end{array}$ & $\begin{array}{c}\text { Albutrepenonacog } \\
\text { alfa }\end{array}$ & Idelvion $^{\circledR}$ & $\begin{array}{l}\text { Coagulation } \\
\text { factor IX }\end{array}$ & Hemophilia B & $\begin{array}{c}\text { CSL } \\
\text { Behring }\end{array}$ & $\begin{array}{l}\text { AEX- } \\
\text { AF- } \\
\text { MMC }\end{array}$ & $\begin{array}{l}\text { Q Sepharose } \\
\text { FF- Heparin } \\
\text { support-CHT }\end{array}$ & 2016 & $\begin{array}{l}\text { Metzner et al. } \\
\text { (2009) }\end{array}$ \\
\hline Glycosylation & Darbepoetin alfa & Aranesp $^{\circledast}$ & $\begin{array}{l}\text { Erythropoetin } \\
\text { (analogue) }\end{array}$ & $\begin{array}{l}\text { Anemia due to chronic } \\
\text { kidney disease or } \\
\text { myelosuppresive } \\
\text { chemotherapy }\end{array}$ & $\begin{array}{l}\text { Amgen } \\
\text { Inc. }\end{array}$ & $\begin{array}{l}\text { AEX- } \\
\text { RPC, } \\
\text { SEC }\end{array}$ & $\begin{array}{l}\text { Q Sepharose } \\
\text { FF, Vydac C4, } \\
\text { Bio-Sil SEC } 250\end{array}$ & 2001 & $\begin{array}{c}\text { Elliot and } \\
\text { Byrne, (1997) }\end{array}$ \\
\hline \multirow[t]{6}{*}{ Lipidation } & Insulin determin & Levemir $^{\circledR}$ & $\begin{array}{c}\text { Insulin } \\
\text { (analogue) }\end{array}$ & $\begin{array}{c}\text { Type } 1 \text { and } 2 \text { diabetes } \\
\text { mellitus }\end{array}$ & $\begin{array}{l}\text { Novo } \\
\text { Nordisk }\end{array}$ & $\mathrm{RPC}$ & NA & 2005 & $\begin{array}{l}\text { Havelund } \\
\text { et al. (1997) }\end{array}$ \\
\hline & Liraglutide & Victoza $^{\circledR}$ & $\begin{array}{c}\text { GLP-1 } \\
\text { (analogue) }\end{array}$ & $\begin{array}{c}\text { Type } 2 \text { diabetes mellitus } \\
\text { and obesity }\end{array}$ & $\begin{array}{l}\text { Novo } \\
\text { Nordisk }\end{array}$ & CEX & Source 305 & 2009 & Staby, (2011) \\
\hline & Liraglutide & Saxenda ${ }^{\circledR}$ & $\begin{array}{c}\text { GLP-1 } \\
\text { (analogue) }\end{array}$ & Management of obesity & $\begin{array}{l}\text { Novo } \\
\text { Nordisk }\end{array}$ & CEX & Source 305 & 2010 & Staby, (2011) \\
\hline & Insulin degludec & Tresiba $^{\circledR}$ & $\begin{array}{l}\text { Insulin } \\
\text { (analogue) }\end{array}$ & $\begin{array}{c}\text { Type } 1 \text { and } 2 \text { diabetes } \\
\text { mellitus }\end{array}$ & $\begin{array}{l}\text { Novo } \\
\text { Nordisk }\end{array}$ & $\begin{array}{l}\text { AEX, } \\
\text { RPC }\end{array}$ & $\begin{array}{l}\text { Source 15Q, } \\
\text { Nucleosil C4 }\end{array}$ & 2013 & $\begin{array}{l}\text { Jonassen } \\
\text { et al. (2009) }\end{array}$ \\
\hline & Semaglutide & Ozempic $^{(}$ & $\begin{array}{c}\text { GLP-1 } \\
\text { (analogue) }\end{array}$ & $\begin{array}{c}\text { Type } 2 \text { diabetes mellitus } \\
\text { and obesity }\end{array}$ & $\begin{array}{l}\text { Novo } \\
\text { Nordisk }\end{array}$ & $\mathrm{RPC}$ & C18 & 2017 & $\begin{array}{l}\text { Lau et al. } \\
\text { (2012) }\end{array}$ \\
\hline & Somapacitan-beco & Sogroya ${ }^{\circledR}$ & $\begin{array}{c}\text { Human growth } \\
\text { hormone } \\
\text { (analogue) }\end{array}$ & $\begin{array}{c}\text { Growth hormone } \\
\text { deficiency }\end{array}$ & $\begin{array}{l}\text { Novo } \\
\text { Nordisk }\end{array}$ & NA & NA & 2020 & $\begin{array}{l}\text { Thygesen } \\
\text { et al. (2017) }\end{array}$ \\
\hline
\end{tabular}

AEX, anion exchange chromatography; AF, affinity chromatography; CEX, cation exchange chromatography; CHT, ceramic hydroxyapatite; CTS, chromatographic techniques sequence; FF, fast flow; GLP-1, glucagon-like peptide-1; NA, information not available; SEC, size exclusion chromatography; RPC, reverse phase chromatography.

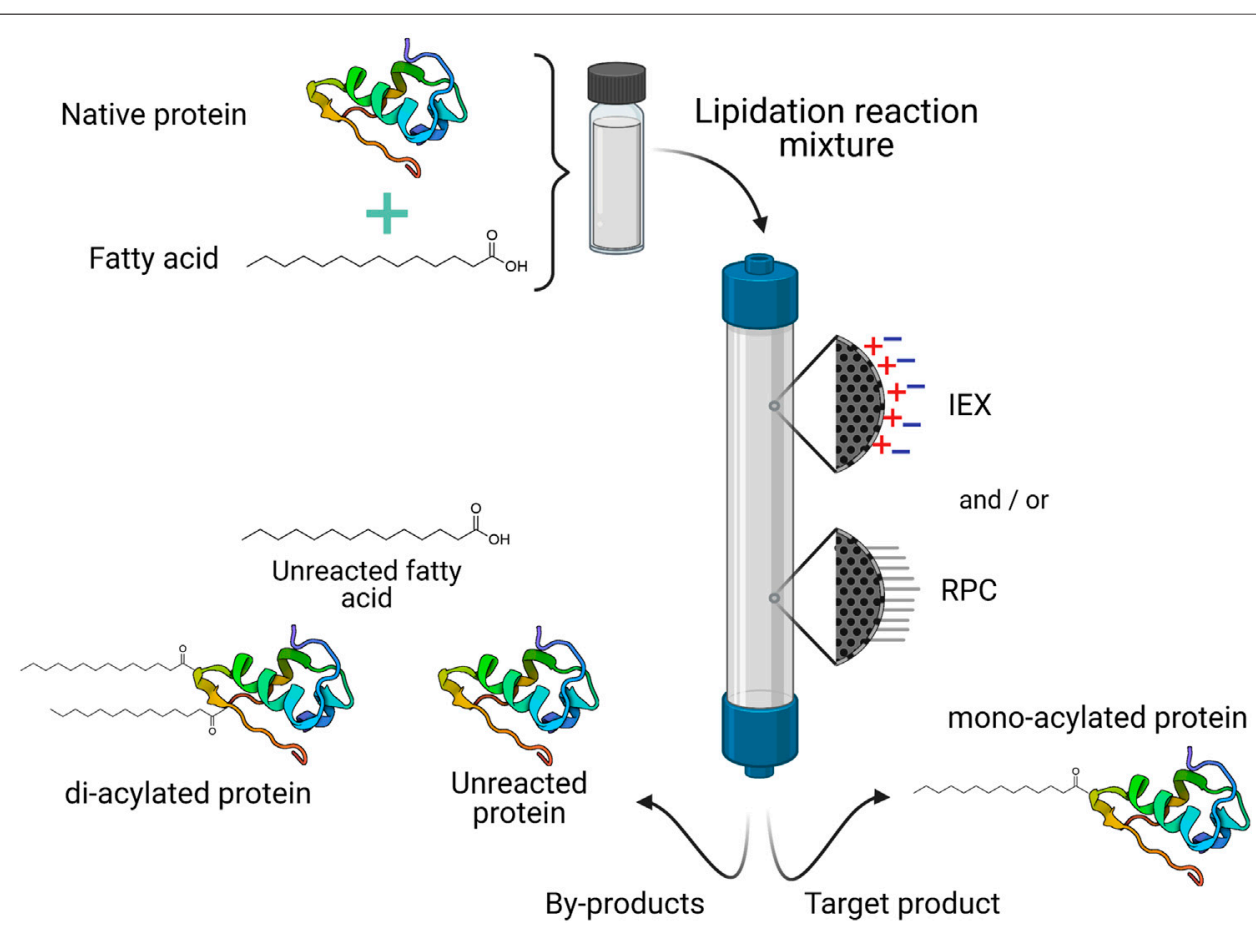

FIGURE 4 | General purification process for commercial lipidated proteins. One or two different chromatographic operational modes may be necessary to isolate the target product (usually the mono-acylated protein) from the lipidation reaction mixture. IEX, ionic exchange chromatography; RPC, reverse phase chromatography.

proteins (Frokjaer and Otzen, 2005). Additionally, lipidation is recognized as a safe modification, since the fatty acids used for this purpose (i.e., myristic and palmitic acids) can be completely metabolized by the human body (van Witteloostuijn et al., 2016). To date, five lipidated therapeutic proteins are available on the market (see Table 5) for the treatment of type 1 and type 2 
diabetes mellitus and related conditions (i.e., obesity and glycemic control). They are composed of either insulin or GLP-1 analogues conjugated to a single long-chain fatty acid. All these therapeutic proteins are manufactured by Novo Nordisk, one of the pioneers in protein lipidation (Kurtzhals et al., 1995).

Similar to PEGylation, lipid conjugation is achieved through chemical reactions between a reactive fatty acid derivative and a pure therapeutic protein. The lipid moiety may be directly attached to an amino acid residue, or via a spacer such as L-glutamic acid. Due to the hydrophobic nature of lipid reactants, in some cases it may be necessary to carry out the reaction in polar organic solvents, or in a mixture of aqueous and water-miscible organic solvents. Solvent selection will depend on the properties and stability of the protein or peptide, and the solubility of reagents (Havelund et al., 1997; Knudsen et al., 2001; Jonassen et al., 2009). The lipidation reaction strategy will influence the chromatographic strategies followed to purify lipidated proteins. Among the main contaminants to be removed after the conjugation reaction are the unmodified protein, di-acylated forms, and unreacted fatty acid (Figure 4).

\section{Purification Strategies}

Reverse phase chromatography (RPC) is employed in most of the purification processes of marketed lipidated proteins, whether as a single purification step (as in the cases of Levemir ${ }^{\circledR}$ and Ozempic ${ }^{\circledR}$ ) or in combination with IEX (Table 5). RPC employs solid supports, usually silica particles, modified with alkyl chains (mainly $\mathrm{C}_{4}, \mathrm{C}_{8}$ or $\mathrm{C}_{18}$ ) to render a hydrophobic stationary phase, which can strongly interact with hydrophobic or low-polarity molecules (Schlüter, 1999; Poole and Lenca, 2017). Since lipidation increases protein hydrophobicity, RPC is particularly useful for the separation of lipidated derivatives from the unmodified protein. In this type of chromatography, elution is carried out by a mixture of water and water-miscible organic solvents with different polarity. Lipidated proteins are eluted by a concentration gradient of ethanol or acetonitrile (Havelund et al., 1997; Schlüter, 1999; Jonassen et al., 2009; Lau et al., 2012). As the solvent concentration increases, the polarity of the mobile phase decreases, and the partition of lipidated proteins will be favored towards the mobile phase and it will elute (Schlüter, 1999).

Among the modified therapeutic proteins discussed in this review, lipidated proteins are the smallest conjugates in terms of molecular weight. Tresiba ${ }^{\circledR}$ (an hexadecandioyl-conjugated insulin analogue for the treatment of type 1 and type 2 diabetes mellitus), the largest of this class, has a molecular weight of $6.1 \mathrm{kDa}$. Additionally, the impurities after the acylation reaction are mainly low molecular weight species as opposed to the high molecular weight contaminants in PEGylation (i.e., unreacted PEG and multi-PEGylated species) or HMWA found in Fc-fusion proteins. The small size of the target conjugates allows the use of stationary phases featuring low particle sizes $(\leq 30 \mu \mathrm{m})$ for RPC and IEX, which contribute to separations with high resolution. In all the cases where RPC is used for the purification of lipidated proteins, semi-preparative HPLC columns are employed. Semi-preparative RP-HPLC is an excellent technique for the purification of small proteins and peptides offering a high resolution (purification factor between 2 and 200) even at large scales (Schlüter, 1999; Josic and Kovac, 2010). Semi-preparative RP-HPLC columns feature low particle sizes $(\leq 15 \mu \mathrm{m})$ with small pores $(100-300 \AA)$, which promote enhanced chromatographic resolution and column efficiency in comparison with other preparative chromatography techniques, such as IEX, SEC and HIC. Moreover, the silica-based matrix of RP-HPLC columns confers great mechanical stability, allowing operation at high flow rates $(200-800 \mathrm{~cm} / \mathrm{h})$ at acceptable backpressure values (Josic and Kovac, 2010).

IEX is also used in the purification processes of marketed lipidated proteins (Table 5). The use of this chromatographic technique follows two different approaches. On one hand, CEX is used as a single purification step for both Victoza ${ }^{\circledR}$ and Saxenda ${ }^{\circledR}$ (a palmitoyl-conjugated GLP-1 analogue), which are used for the treatment of type 2 diabetes mellitus and obesity management, respectively. On the other hand, AEX is used prior to RPC in the purification of Tresiba ${ }^{\circledR}$ (Jonassen et al., 2009; Staby, 2011).

The purification of Tresiba ${ }^{\circledR}$ begins with the precipitation of the crude product from the reaction mixture. Then, it is resuspended in an aqueous/ethanol buffer at $\mathrm{pH} 7.5$ and loaded into a column packed with Source 15Q (Cytiva), a strong AEX resin (Jonassen et al., 2009). The pI of insulin degludec (the component in Tresiba ${ }^{\circledR}$ ) is similar to that of native insulin, which is around 5.6 (Kohn et al., 2007; Wang et al., 2012). Therefore, at loading $\mathrm{pH}$ insulin degludec binds to the resin, while certain impurities are lost in the flow-through. Elution is performed with an ammonium acetate gradient, from 0.24 to $1.25 \% \mathrm{w} / \mathrm{w}$, and target-containing fractions are subjected to purification by RP-HPLC using a Nucleosil C4 250/10 mm, $10 \mu \mathrm{m}, 300 \AA$ column, where elution is carried out by an ethanol gradient (from 7 to $42 \% \mathrm{v} / \mathrm{v}$ ). The purity of insulin degludec after AEX is $72.9 \%$ and it increases to $99.4 \%$ after semi-preparative RPHPLC. However, during the RP-HPLC step, $50 \%$ of the loaded target product is lost. Although semi-preparative RP-HPLC excels in delivering the target product at a superior purity, it does so at expenses of productivity. Therefore, a thorough optimization of this chromatographic technique is crucial to increase yield without compromising purity. Semi-preparative RP-HPLC combined with IEX is considered an essential method for the separation and characterization of proteins in a complex mixture (Josic and Kovac, 2010).

Staby described the use of CEX as a single chromatography step for the purification of both Victoza ${ }^{\circledR}$ and Saxenda ${ }^{\circledR}$ (Staby, 2011). The crude reaction mixture after acylation, comprising mono-, di-acylated and unmodified GLP-1, was loaded into a column packed with Source 30S (Cytiva), a strong CEX resin, equilibrated with an aqueous/ethanol buffer at $\mathrm{pH} 3.5$. Using a linear salt gradient from 0 to $1.30 \% \mathrm{w} / \mathrm{w} \mathrm{KCl}$, the successful separation of di-acylated, mono-acylated (desired product) and unmodified GLP-1 (following this elution order) was achieved. This indicates that the acylation process modifies the protein's physicochemical properties, specifically its surface net charge, making the use of IEX feasible for the purification of the target product.

An interesting aspect regarding the elution mode in IEX steps of Tresiba ${ }^{\circledR}$ and Victoza ${ }^{\circledR} /$ Saxenda ${ }^{\circledR}$, is the narrow salt gradient 
used to elute proteins. The equilibrium and elution buffer in both cases contained a large concentration of ethanol: $42 \% \mathrm{w} / \mathrm{w}$ and $64.5 \% \mathrm{w} / \mathrm{w}$ for Tresiba ${ }^{\circledR}$ and Victoza ${ }^{\circledR} /$ Saxenda ${ }^{\circledR}$, respectively. The addition of organic solvents to the mobile phase in IEX changes the selectivity and capacity factor by modifying the electrostatic interactions between the analytes and the stationary phase, contributing to the separation of analytes (Craig, 2012).

\section{Trends in Lipidated Proteins Purification}

Regarding the chromatography strategies implemented for the purification of lipidated proteins, semi-preparative RP-HPLC is still the most prevalent. However, the application of a single IEX step, as in the case of Victoza ${ }^{\circledR}$ and Saxenda ${ }^{\circledR}$, represents significant advantages, from which cost and time savings are the most relevant, given the lower costs and higher throughput of IEX compared to semi-preparative RP-HPLC (Knudsen et al., 2001).

Lipidation has proven to be successful, as evidenced by currently available commercial formulations. Although only acylated insulin and GLP-1 analogues have reached the market, the principle of lipidation has been applied and evaluated for other proteins and peptides, such as interferon alpha (Yuan et al., 2008) and desmopressin (Wang et al., 1999).

\section{OTHER MODIFICATIONS}

\section{Glycosylation}

Glycosylation involves the covalent attachment of a carbohydrate moiety to a protein (Solá and Griebenow, 2010). It is one of the most important and complex post-translational modifications. Approximately $50-60 \%$ of all human proteins are glycosylated, either by the addition of $\mathrm{N}$ - or O-linked glycans (Roucka et al., 2018). Glycosylation has been used as an effective strategy to optimize therapeutic proteins efficacy (Solá and Griebenow, 2010). This is due to the fact that glycosylation has many functions including stabilization of protein conformation, control of protein folding, modulation of immunogenicity, and regulation of signal transduction, cell adhesion and half-life (Berger et al., 2011; van Witteloostuijn et al., 2016).

In nature, glycoproteins are obtained by a complex process involving several enzymes from different pathways (Berger et al., 2011). In counterpart, many glycosylated therapeutic proteins are produced by genetic engineering approaches using a wide variety of expression hosts that somehow mimic the human glycosylation pattern (van Witteloostuijn et al., 2016). However, proteins are often obtained as a mixture of multiple glycoforms, which may have significant variations in biological activity (Lingg et al., 2012; Roucka et al., 2018). To address this issue, several strategies have emerged, including enzymatic and chemical synthesis, and manipulation of biosynthetic pathways in different expression hosts ( $\mathrm{Li}$ and Wang, 2018). Furthermore, glycosylation profiles are highly influenced by upstream and downstream processes conditions, making necessary systematic monitoring throughout development and manufacturing processes (Zhang et al., 2016).
Currently, there are several glycosylated therapeutic proteins available on the market. Most of them are either naturally glycosylated or their glycosylation pattern has been modified. In this review, focus will be placed in the purification process of marketed glycosylated therapeutic proteins containing additional glycosylation sites (added by genetic engineering approaches) to those occurring naturally. Until now, there is only one therapeutic protein available on the market that has been hyperglycosylated to optimize its biological activity: Aranesp ${ }^{\circledR}$, which is an analogue of erythropoietin used for the treatment of anemia due to chronic kidney disease or myelosuppressive chemotherapy (Table 5). Aranesp $^{\circledR}$ has a higher sialic acid content than native erythropoietin. Sialic acid is a negatively charged monosaccharide. In consequence, an increase of sialic acid in the protein can alter its surface charge and pI, which have been related to increased circulatory half-life of glycosylated proteins (Solá and Griebenow, 2010).

Aranesp ${ }^{\circledR}$ is produced using recombinant Chinese hamster ovary $(\mathrm{CHO})$ cells. Thus, its downstream processing focuses on isolating the glycoform of interest, containing five $\mathrm{N}$-linked oligosaccharide chains, and removing contaminants, such as DNA, cell debris, endotoxins, HCP, media components and viruses. First, cell culture media is loaded to an AEX column, packed with Q Sepharose FF resin (Cytiva), using an equilibration buffer (Tris $10 \mathrm{mM} \mathrm{pH} \mathrm{8.5)} \mathrm{that} \mathrm{allows} \mathrm{binding} \mathrm{of} \mathrm{the} \mathrm{multiple}$ erythropoietin glycoforms to the resin. The rationale behind the use of this technique is that the negative charge of the protein increases depending on its sialic acid content. The elution of glycoforms that remain bound to the AEX column is achieved by a $50 \mathrm{CV}$ linear gradient of $\mathrm{NaCl}$ ranging from 0 to $0.5 \mathrm{M}$. A long linear gradient allows a better separation of protein glycoforms which are just slightly different. Afterwards, RPC is used as a first polishing step. The additional sialic acids in the protein alter its hydrophobicity, making the use of this technique feasible for the separation of glycoforms (Vreeker and Wuhrer, 2017). The fractions from AEX are pooled and loaded into a C4 column (Vydac ${ }^{\circledR}$, Hichrom Limited). The elution of the glycoform of interest is accomplished by a $30 \mathrm{CV}$ gradient of ethanol ranging from 20 to $94 \% \mathrm{v} / \mathrm{v}$.

The last polishing step of Aranesp ${ }^{\circledR}$ involves the use of HPLCSEC. Glycan moieties often contribute in a considerable manner to the mass of glycosylated proteins. Two different pools were obtained from the RPC step: one containing the glycoform of interest and another containing the glycoform of interest and aggregates. These pools were loaded separately to a HPLC-SEC column (Biosil SEC 250, Bio-Rad) and peaks corresponding to the monomeric glycoform were collected. The use of SEC for separation of glycosylated proteins and peptides presents special difficulties because their molecular size and shape are subjected to large variations with the mobile phase ionic strength and $\mathrm{pH}$. The $\mathrm{pH}$ and ionic strength of the mobile phase should also be selected carefully to avoid interactions of the glycosylated proteins among each other or with the matrix of the stationary phase, which may result in distorted peaks and altered elution of the proteins (Churms, 2002). Although SEC may be performed at a large scale, its use is preferred in the final stages of protein purification. This is because at final purification stages, the sample 
volume is reduced making feasible the use of smaller SEC columns. Also, the use of smaller columns reduces run times and the amount of required chromatographic media, diminishing operating costs.

\section{Albumin-Fusion}

Human albumin, produced mainly in the liver, is a highly watersoluble and the most abundant protein in plasma, with a very long circulation half-life (19 days on average) (Kratz, 2008). Due to these features, it has been used to improve the pharmacokinetic and physicochemical characteristics of some therapeutics. Proteins can be linked to albumin either by non-covalent interactions (by specific moieties that bind to albumin) or covalent bonds (by chemical conjugation or genetic engineering fusion) (Sleep et al., 2013). The attachment of proteins to albumin has been intensively studied in the last decades. However, until now, only one albumin-fusion therapeutic protein is available on the market: Idelvion $^{\circledR}$ (coagulation factor IX to treat hemophilia B, Table 5).

The production of Idelvion ${ }^{\circledR}$ is carried out by extracellular expression in $\mathrm{CHO}$ cells. Thus, its purification process is focused on the clearance of HCP, nucleic acids, and other contaminants, following a very similar scheme to that used for Fc-fusion proteins. As a capture step, Q sepharose FF resin (Cytiva) is employed, and elution is accomplished by a $\mathrm{NaCl} / \mathrm{CaCl}_{2}$ step gradient. The rationale of the use of $\mathrm{Q}$ Sepharose FF (Cytiva), a strong AEX support, and the elution with $\mathrm{NaCl} / \mathrm{CaCl}_{2}$ in the capture step of Idelvion ${ }^{\circledR}$ is deeply discussed further in Case Study: Purification of Modified Coagulation Factor IX. A heparin affinity support is used as the first polishing step, using a $\mathrm{NaCl}$ step gradient elution. Heparin is a highly sulfonated (negatively charged) polydisperse linear polysaccharide. Chromatographic supports featuring immobilized heparin can be employed to purify different types of proteins, such as enzymes, serine protease inhibitors, growth factors, antithrombin III antibodies, extracellular matrix proteins, coagulation factors, DNA-binding proteins, lipoproteins, and hormone receptors (Xiong et al., 2008). Conveniently, heparin can act as an affinity ligand with biological specificity, but also as a cation exchanger (Xiong et al., 2008; Bolten et al., 2018).

The second and last polishing step of the purification process of Idelvion ${ }^{\circledR}$ is carried out using ceramic hydroxyapatite particles (CHT) (Bio-Rad) and a step gradient elution with sodium phosphate (Metzner et al., 2009). CHT particles are produced by spray-drying hydroxyapatite nanocrystals to obtain porous beads of $20-80 \mu \mathrm{m}$, which are suitable for protein chromatography. The beads are sintered at high temperature to stabilize the structure and gain mechanical stability. Depending on the sintering temperature, properties such as porosity and pore size may vary. A wide range of CHT resins are commercially available with different properties and applications (Wang and Carta, 2019). The type of CHT used in Idelvion ${ }^{\circledR}$ purification process is not reported; however, BioRad commercializes two different types of CHT resins: type 1 and type 2 . Both have a nominal particle size of $40 \mu \mathrm{m}$ but differ in its porosity and surface area. CHT type 1 has a smaller pore size (30 vs. $49 \mathrm{~nm}$ ) but a larger surface area ( $48 \mathrm{vs.} 30 \mathrm{~m}^{2} / \mathrm{ml}$ particle) in comparison to CHT type 2 (Wang and Carta, 2019). CHT type 2 has been used to recover native coagulation factor IX and its recombinant form fused with prothrombin propeptide by showing high affinity and selectivity to the CHT support (Blostein et al., 2008).

\section{CASE STUDY: PURIFICATION OF MODIFIED COAGULATION FACTOR IX}

Coagulation factor IX (FIX), a protein with a molecular mass around $57 \mathrm{kDa}$, plays a key role in the blood coagulation system. The deficiency of FIX produces hemophilia B, which causes frequent spontaneous bleeding episodes in different tissues (Metzner et al., 2009; Santagostino et al., 2012). To treat hemophilia B, different FIX products have been manufactured, including plasma-derived (e.g., Immunine $\mathrm{VH}^{\circledR}$, Mononine ${ }^{\circledR}$ ) and recombinant FIX (e.g., BeneFIX ${ }^{\circledR}$, Ixinity ${ }^{\circledR}$, Rixubis $^{\circledR}$ ) (Mannucci and Franchini, 2014; Morfini and Zanon, 2016). Recombinant modified FIX versions such as PEGylated (Rebinyn $\left.{ }^{\circledR}\right), \quad$ Fc-fused $\quad\left(\right.$ Alprolix $\left.{ }^{\circledR}\right)$, and albumin-fused (Idelvion ${ }^{\circledR}$ ) are highlighted due to their extended clearance time. Regarding the purification process, the chromatography strategies to purify these modified versions of FIX are compared in Figure 5.

Despite that different moieties are linked to FIX, all three modified FIX forms have one chromatographic step in common: an AEX step using chromatographic supports bearing quaternary amines. In all cases, a low ionic strength mobile phase with $\mathrm{NaCl} /$ $\mathrm{CaCl}_{2}$ was used to elute the modified FIX. FIX has a pI between 4.0 and 5.0 (Santagostino et al., 2012; Lee et al., 2014). Therefore, at neutral and basic $\mathrm{pH}$ values the protein can bind to the AEX support. The elution strategy exploits the structural properties of FIX. FIX is a vitamin K-dependent protein that requires calcium ions for proper biological activity. Once calcium ions are bound to FIX, the protein goes through conformational changes which can affect the surface charge (Yan, 1996; Blostein et al., 2008). Following this rationale, once the column has been loaded and the proteins have bound to the resin, a low $\mathrm{CaCl}_{2}$ concentration $(50 \mathrm{mM})$ will detach FIX from the column by the loss of interactions caused by the conformational changes of the protein, while undesired proteins and contaminants will remain bound to the column.

The number of chromatographic steps in the downstream processing of modified therapeutic proteins will depend directly on the selected type of modification. The purification of PEGylated FIX requires only one chromatographic step (using POROS $50 \mathrm{HQ}$ resin) because FIX is already pure prior to the PEGylation reaction. In contrast, the purification strategy of Alprolix ${ }^{\circledR}$ and Idelvion $^{\circledR}$ requires a multi-step chromatographic approach, consisting of a capture step followed by two polishing steps. Both therapeutic proteins are produced in $\mathrm{CHO}$ cells and secreted to the culture medium and thus, a higher number of impurities must be removed.

In the case of Alprolix ${ }^{\circledR}$, the capture step is focused in taking advantage of the high affinity of protein A ligand for the Fc region of the conjugate. Then, a weak AEX resin (diethylaminoethyl 

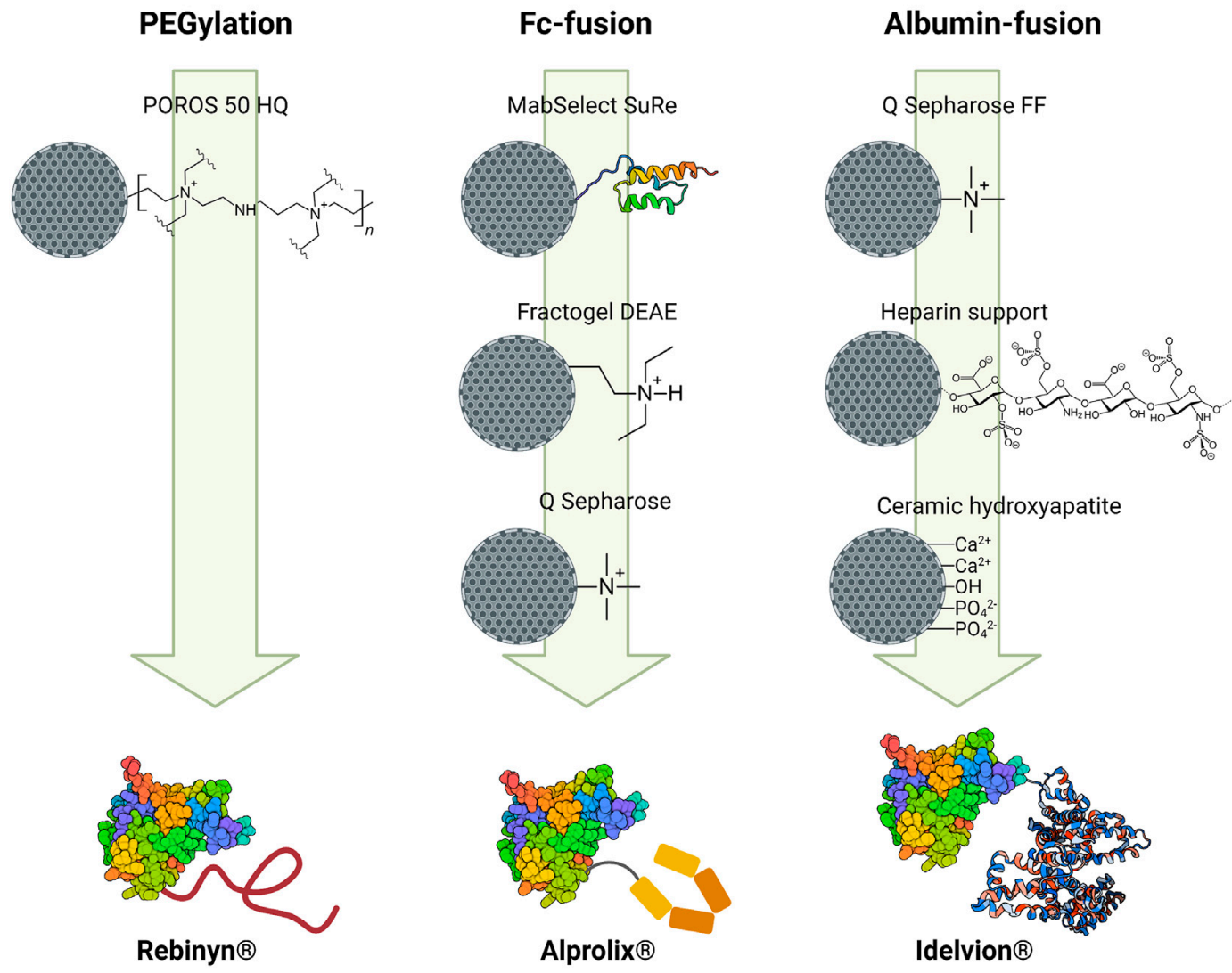

FIGURE 5| Chromatographic strategies followed to purify the three different versions of modified coagulation factor IX. For each modification, resins (depicting their ligands) are placed in order according to the downstream process. The modified proteins representations are illustrative, and they do not reflect the actual location of the conjugation.

ligand) is employed to eliminate impurities and leached protein A. To achieve the required purity level, a second polishing step is applied with strong AEX (quaternary ammonium ligand) using the $\mathrm{CaCl}_{2}$ elution approach. The purification of Idelvion ${ }^{\circledR}$ involves Q Sepharose FF resin (Cytiva) as a capture step and $\mathrm{CaCl}_{2}$ for elution. IEX is commonly used for capture in part because of the high binding capacity that can be achieved. This feature, in addition to the FIX-selectivity of $\mathrm{CaCl}_{2}$ elution, makes it a suitable option for the capture step of Idelvion ${ }^{\circledR}$. Afterwards, polishing steps are employed using heparin affinity ligand and $\mathrm{CHT}$ particles. Heparin ligand has affinity to coagulation factors but also to a broad range of other proteins; therefore, an additional purification step is necessary to ensure the complete removal of contaminant proteins and achieve the required purity. CHT particles have demonstrated high affinity and selectivity to native FIX; furthermore, the small particle size of CHT and their reduced pore size can provide a high resolution. In summary, the comparison of the purification processes of different modified
FIX therapeutics revealed that structural properties of both, FIX and the conjugated moiety play a key role in the selection of the chromatographic techniques and the sequence to be employed. Additionally, the starting material (cell culture media or reaction buffer) must be considered to recognize the type and burden of impurities to be removed.

\section{CONCLUSIONS AND PERSPECTIVES}

Undoubtedly, given their superior pharmacokinetic and pharmacodynamic properties, more biopharmaceuticals based on modified therapeutic proteins will be developed and will reach the market in upcoming years. It is fair to say that due to the great impurity removal capacity of chromatography, this technique will continue to be the core of the downstream processing for modified therapeutic proteins. Therefore, the understanding of the rationale 
behind the selection of operating parameters for chromatographic processes (binding conditions, elution mode, ligand, resin, etc.) becomes crucial to increase the process yield, without compromising product purity.

The first aspect to consider is where the modified protein is being isolated from, which can be either a reaction mixture (starting with the pure protein) or a cell culture supernatant. This will determine the number and modes of chromatographic steps needed. Modified proteins from cell culture media (Fc-fusion, albumin-fusion, or glycosylation) may need up to four chromatographic steps; meanwhile PEGylated and lipidated proteins may only require one chromatographic step depending on the desired target product. As analyzed with the case study of coagulation factor IX, the moiety attached to the protein will determine the appropriate chromatographic modes to be employed and their sequence. It is essential to recognize or characterize the physicochemical properties of the native protein (e.g., hydrophobicity, surface charge, size, and affinity to certain ligands) and analyze which of these could be altered after conjugation in order to design a preliminary purification strategy.

Nowadays, novel stationary phases with enhanced properties are in development. Greater physical and chemical stability, high binding capacity, and high resolution will allow the operation of chromatographic columns at challenging industrial process conditions, such as high flow rates, while maintaining product recovery and purity. Among the new stationary phases with promising applications, MMC mode is highlighted since it provides versatility on ligand selection with high resolution in chromatography; although improvement of the backbone matrix of these resins is still needed to avoid non-specific interactions, increase lifetime, mechanical stability, and binding capacity. Despite that several resins with enhanced properties have been designed, produced, and tested, many of those chromatographic materials remain at experimental stages; probably because their application at large-scale have not achieved acceptable performances yet. Hence, most of the current purification processes rely on conventional, commercially available chromatographic supports. It is worthy to mention that all purification processes presented in this revision rely on the state of the art when all the biopharmaceuticals were developed. Therefore, it is feasible that all new chromatographic materials can be reported in more recently approved products.

\section{REFERENCES}

Ahamed, T., Chilamkurthi, S., Nfor, B. K., Verhaert, P. D., van Dedem, G. W., van der Wielen, L. A., et al. (2008). Selection of pH-Related Parameters in IonExchange Chromatography Using $\mathrm{pH}-\mathrm{Gradient}$ Operations. J. Chromatogr. A. 1194, 22-29. doi:10.1016/j.chroma.2007.11.111

Alibolandi, M., and Mirzahoseini, H. (2011). Chemical Assistance in Refolding of Bacterial Inclusion Bodies. Biochem. Res. Int. 2011, 1-6. doi:10.1155/2011/631607 Angelo, J. M., and Lenhoff, A. M. (2016). Determinants of Protein Elution Rates from Preparative Ion-Exchange Adsorbents. J. Chromatogr. A. 1440, 94-104. doi:10.1016/j.chroma.2016.02.048
Chromatographic operational parameters must be carefully thoroughly selected to attain the best possible performance with currently available resins. For all chromatographic modes, different elution conditions can be explored to optimize process performance, although this selection process is resource- and time-consuming. Fortunately, high throughput screening (HTS) methodologies are available, which can produce a massive amount of data through miniaturization and parallelization of experiments allowing the analysis of orthogonality and separability of resins. Combining the data generation power of HTS along with statistical tools, such as design of experiments, a much faster and guided process to establish customized, efficient, and cost-effective methodologies is obtained.

On the other hand, process integration, such as on-column PEGylation or lipidation, and continuous operations can also contribute to streamline the purification process and increase productivity. This approach, although still under development, is considered as a promising strategy since it reduces the number of unit operations required for the purification process and in consequence, cost and time are diminished.

Downstream processing continues to be the bottleneck of many biopharmaceutical manufacturing processes. Therefore, to the extent that this stage is truly optimized, the manufacturing process will flow more efficiently and satisfying the continuously increasing demand.

\section{AUTHOR CONTRIBUTIONS}

CS-T, MF-G, and DE-O contributed with bibliographic revision, writing, and editing of all sections. MR-P reviewed and edited the final version of the manuscript. KM-D provided the context and structure of the manuscript and edited the final version. All authors approved the final version of the manuscript prior to submission.

\section{ACKNOWLEDGMENTS}

The authors thank the Translational Omics and Bioengineering and Regenerative Medicine Focus Groups from Tecnologico de Monterrey. CS-T, MF-G, and DE-O acknowledge CONACyT for their respective research scholarships 492276, 744118, and 712327. All figures were created with BioRender.com.

Arakawa, T., Philo, J. S., Tsumoto, K., Yumioka, R., and Ejima, D. (2004). Elution of Antibodies from a Protein-A Column by Aqueous Arginine Solutions. Protein Expr. Purif. 36, 244-248. doi:10.1016/j.pep.2004.04.009

Assadourian, S., Castan, R., and Magherini, E. (2014). Article of Manufacture Comprising Aflibercept or Ziv-Aflibercept. Canadian Patent No. 2888281 A1. Gatineau: Canadian Intellectual Property Office.

Avallin, J., Nilsson, A., Asplund, M., Pettersson, N., Searle, T., and Jägersten, C. (2016). Columns up to $1600 \mathrm{Mm}$ in Diameter Packed with Protein A Chromatography Medium Using Axial Mechanical Compression. Application Note 29177970 AB. UppsalaSweden: GE Healthcare, 291.

Awwad, S., Ginn, C., and Brocchini, S. (2018). "The Case for Protein PEGylation," in Engineering of Biomaterials for Drug Delivery Systems: Beyond Polyethylene 
Glycol. Editor A. Parambath (Duxford, United Kingdom: Woodhead Publishing), 27-49. doi:10.1016/B978-0-08-101750-0.00002-7

Bailon, P. S. (2008). G-CSF Conjugates. U.S. Patent No. 2008/0287659 A1. Washington, DC: U.S. Patent and Trademark Office.

Baumann, P., and Hubbuch, J. (2017). Downstream Process Development Strategies for Effective Bioprocesses: Trends, Progress, and Combinatorial Approaches. Eng. Life Sci. 17, 1142-1158. doi:10.1002/elsc.201600033

Bell, S. M., Wendt, D. J., Zhang, Y., Taylor, T. W., Long, S., Tsuruda, L., et al. (2017). Formulation and PEGylation Optimization of the Therapeutic PEGylated Phenylalanine Ammonia Lyase for the Treatment of Phenylketonuria. PLoS One 12, e0173269. doi:10.1371/journal.pone.0173269

Berger, M., Kaup, M., and Blanchard, V. (2011). "Protein Glycosylation and its Impact on Biotechnology," in Genomics and Systems Biology of Mammalian Cell Culture. Editors W. Hu and AP. Zeng (Berlin, Heidelberg: Springer), 165-185. doi:10.1007/10_2011_101:

Blostein, M., Cuerquis, J., Landry, S., and Galipeau, J. (2008). The Carboxylation Efficiency of the Vitamin K-dependent Clotting Factors: Studies with Factor IX. Haemophilia 14, 1063-1068. doi:10.1111/j.1365-2516.2008.01828.x

Bolten, S. N., Rinas, U., and Scheper, T. (2018). Heparin: Role in Protein Purification and Substitution with Animal-Component Free Material. Appl. Microbiol. Biotechnol. 102, 8647-8660. doi:10.1007/s00253-018-9263-3

Bossard, M. J., Bentley, M. D., and Zhang, P. (2012). Polymer Factor VIII Moiety Conjugates. U.S. Patent No. 8143378 B2. Washington, DC: U.S. Patent and Trademark Office.

Brown, A., Bechtel, C., Bill, J., Liu, H., Liu, J., McDonald, D., et al. (2010). Increasing Parvovirus Filter Throughput of Monoclonal Antibodies Using Ion Exchange Membrane Adsorptive Pre-filtration. Biotechnol. Bioeng. 106, 627-637. doi:10.1002/bit.22729

Burg, J., Engel, A., Franze, R., Hilger, B., Schuring, H. E., Tischer, W., et al. (2011). Conjugates of Erythropoietin (Epo) with Polyethylene Glycol (Peg). European Patent No. 1345628 B1. Munich, Germany: European Patent Office.

Carta, G., and Jungbauer, A. (2010). Protein Chromatography: Process Development and Scale-Up. Weinheim: Wiley-VCH Verlag. doi:10.1002/9783527630158.ch3

Carta, G., Ubiera, A. R., and Pabst, T. M. (2005). Protein Mass Transfer Kinetics in Ion Exchange media: Measurements and Interpretations. Chem. Eng. Technol. 28, 1252-1264. doi:10.1002/ceat.200500122

Chapman, A. P., Antoniw, P., Spitali, M., West, S., Stephens, S., and King, D. J. (1999). Therapeutic Antibody Fragments with Prolonged In Vivo Half-Lives. Nat. Biotechnol. 17, 780-783. doi:10.1038/11717

Chaudhary, R., Balhara, M., and Chhillar, A. K. (2017). "Protein Therapeutic: Production, Application, and Future Scenario," in Metabolic Engineering for Bioactive Compounds: Strategies and Processes. Editors V. C. Kalia and A. K. Saini (Singapore: Springer), 73-88. doi:10.1007/978-981-10-5511-9_4

Chen, B., Sun, Y., Niu, J., Jarugumilli, G. K., and Wu, X. (2018). Protein Lipidation in Cell Signaling and Diseases: Function, Regulation, and Therapeutic Opportunities. Cell Chem. Biol. 25, 817-831. doi:10.1016/ j.chembiol.2018.05.003

Chu, W. N., Wu, Q. C., Yao, S. J., and Lin, D. Q. (2018). High-throughput Screening and Optimization of Mixed-Mode Resins for Human Serum Albumin Separation with Microtiter Filter Plate. Biochem. Eng. J. 131, 47-57. doi:10.1016/j.bej.2017.12.001

Churms, S. C. (2002). "Modern Size-Exclusion Chromatography of Carbohydrates and Glycoconjugates," in Carbohydrate Analysis by Modern Chromatography and Electrophoresis. Editor Z. El Rassi (Amsterdam, Netherlands: Elsevier), 267-303. doi:10.1016/S0301-4770(02)80033-1:

Cisneros-Ruiz, M., Mayolo-Deloisa, K., Przybycien, T. M., and Rito-Palomares, M. (2009). Separation of PEGylated from Unmodified Ribonuclease A Using Sepharose media. Sep. Purif. Technol. 65, 105-109. doi:10.1016/ j.seppur.2008.10.038

Clark, R., Olson, K., Fuh, G., Marian, M., Mortensen, D., Teshima, G., et al. (1996). Long-acting Growth Hormones Produced by Conjugation with Polyethylene Glycol. J. Biol. Chem. 271, 21969-21977. doi:10.1074/jbc.271.36.21969

Conley, L., Tao, Y., Henry, A., Koepf, E., Cecchini, D., Pieracci, J., et al. (2017). Evaluation of Eco-Friendly Zwitterionic Detergents for Enveloped Virus Inactivation. Biotechnol. Bioeng. 114, 813-820. doi:10.1002/bit.26209

Cooney, J. M. (1984). Chromatographic Gel Media for Large Scale Protein Purification. Nat. Biotechnol. 2, 41-55. doi:10.1038/nbt0184-41
Craig, W. H. (2012). Modulation of Ion-Exchange Chromatographic Selectivity through the Addition of Organic Modifiers. [Florida (FL)]: The Florida State University. [dissertation/Ph.D thesis].

Cytiva (2010). Strategies for Protein Purification Handbook. Available at: https:// www.cytivalifesciences.com/en/us/support/handbooks (Accesed July 13, 2020).

Czajkowsky, D. M., Hu, J., Shao, Z., and Pleass, R. J. (2012). Fc-fusion Proteins: New Developments and Future Perspectives. EMBO Mol. Med. 4, 1015-1028. doi:10.1002/emmm.201201379

Dalbøge, L. S., Pedersen, S. L., Van Witteloostuijn, S. B., Rasmussen, J. E., Rigbolt, K. T. G., et al. (2015). Synthesis and Evaluation of Novel Lapidated Neuromedin U Analogs with Increased Stability and Effects on Food Intake. J. Pept. Sci. 21, 85-94. doi:10.1002/psc.2727

Davis, S., Abuchowski, A., Park, Y. K., and Davis, F. F. (1981). Alteration of the Circulating Life and Antigenic Properties of Bovine Adenosine Deaminase in Mice by Attachment of Polyethylene Glycol. Clin. Exp. Immunol. 46, 649-652.

Dimitrov, D. S. (2012). "Therapeutic Proteins," in Methods in Molecular Biology. Editors V. Voynov and J. A. Caravella (Totowa, NJ: Humana Press), 1-26. doi:10.1007/978-1-61779-921-1_1

Duivelshof, B. L., Murisier, A., Camperi, J., Fekete, S., Beck, A., Guillarme, D., et al. (2021). Therapeutic Fc-Fusion Proteins: Current Analytical Strategies. J. Sep. Sci. 44, 35-62. doi:10.1002/jssc.202000765

Dumont, J. A., Liu, T., Low, S. C., Zhang, X., Kamphaus, G., Sakorafas, P., et al. (2012). Prolonged Activity of a Recombinant Factor VIII-Fc Fusion Protein in Hemophilia A Mice and Dogs. Blood 119, 3024-3030. doi:10.1182/blood-201108-367813

Economides, A. N., Carpenter, L. R., Rudge, J. S., Wong, V., Koehler-Stec, E. M., Hartnett, C., et al. (2003). Cytokine Traps: Multi-Component, High-Affinity Blockers of Cytokine Action. Nat. Med. 9, 47-52. doi:10.1038/nm811

Elliot, S. G., and Byrne, T. E. (1997). Erythropoietin Analogs with Additional Glycosylation Sites. European Patent No. 0640619 B1. Munich, Germany: European Patent Office.

Fahrner, R. L., Iyer, H. V., and Blank, G. S. (1999). The Optimal Flow Rate and Column Length for Maximum Production Rate of Protein A Affinity Chromatography. Bioproc. Eng. 21, 287-292. doi:10.1007/s004490050677

Fee, C. J., and Van Alstine, J. M. (2004). Prediction of the Viscosity Radius and the Size Exclusion Chromatography Behavior of PEGylated Proteins. Bioconjug. Chem. 15, 1304-1313. doi:10.1021/bc049843w

Fee, C. J., and Van Alstine, J. M. (2006). PEG-proteins: Reaction Engineering and Separation Issues. Chem. Eng. Sci. 61, 924-939. doi:10.1016/j.ces.2005.04.040

Fee, C. J., and Van Alstine, J. M. (2011). "Purification of PEGylated Proteins," in Protein Purification: Principles, High Resolution Methods, and Applications. Editor J. C. Janson. Third Edition (Hoboken, NJ: John Wiley \& Sons), 339-362. doi:10.1002/9780470939932.ch14

Fee, C. J. (2009). "Protein Conjugates Purification and Characterization, Ed.," in PEGylated Protein Drugs: Basic Science and Clinical Applications. Editor F M. Veronese (Berlin: Birkhäuser Verlag), 113-125. doi:10.1007/978-37643-8679-5_7

Filpula, D. R., and Sapra, P. (2014). Adenosine Deaminase Anticancer Therapy. U.S. Patent No. 8741283 B2. Washington, DC: U.S. Patent and Trademark Office.

Fischer, B., Mitterer, A., and Dorner, F. (1995). Purification of Recombinant Human Coagulation Factors II and IX and Protein S Expressed in Recombinant Vaccinia Virus-Infected Vero Cells. J. Biotechnol. 38, 129-136. doi:10.1016/ 0168-1656(94)00124-U

Follman, D. K., and Fahrner, R. L. (2004). Factorial Screening of Antibody Purification Processes Using Three Chromatography Steps without Protein A. J. Chromatogr. A. 1024, 79-85. doi:10.1016/j.chroma.2003.10.060

Foser, S., Schacher, A., Weyer, K. A., Brugger, D., Dietel, E., Marti, S., et al. (2003). Isolation, Structural Characterization, and Antiviral Activity of Positional Isomers of Monopegylated Interferon $\alpha-2 a$ (PEGASYS). Protein Expres. Purif. 30, 78-87. doi:10.1016/S1046-5928(03)00055-X

Frokjaer, S., and Otzen, D. E. (2005). Protein Drug Stability: A Formulation challenge. Nat. Rev. Drug Discov. 4, 298-306. doi:10.1038/nrd1695

Gagnon, P. (2009). Monoclonal Antibody Purification with Hydroxyapatite. New Biotechnol. 25, 287-293. doi:10.1016/j.nbt.2009.03.017

Gagnon, P. (2012). Technology Trends in Antibody Purification. J. Chromatogr. A. 1221, 57-70. doi:10.1016/j.chroma.2011.10.034 
García, M., Marina, M., and Torre, M. (2000). Perfusion Chromatography: an Emergent Technique for the Analysis of Food Proteins. J. Chromatogr. A. 880, 169-187. doi:10.1016/S0021-9673(00)00354-X

Gašperšič, J., Podgornik, A., Kramberger, P., Jarc, M., Jančar, J., Žorž, M., et al. (2016). Separation of Pegylated Recombinant Proteins and Isoforms on CIM Ion Exchangers. J. Chromatogr. B: Anal. Technol. Biomed. Life Sci. 1033-1034, 91-96. doi:10.1016/j.jchromb.2016.07.020

Ghose, S., Hubbard, B., and Cramer, S. M. (2006). Evaluation and Comparison of Alternatives to Protein A Chromatography. Mimetic and Hydrophobic Charge Induction Chromatographic Stationary Phases. J. Chromatogr. A. 1122, 144-152. doi:10.1016/j.chroma.2006.04.083

Ghose, S., Hubbard, B., and Cramer, S. M. (2007). Binding Capacity Differences for Antibodies and Fc-Fusion Proteins on Protein A Chromatographic Materials. Biotechnol. Bioeng. 96, 768-779. doi:10.1002/bit.21044

Gilbert, C. W., and Cho, M.-O. (1998). Improved Interferon Polymer Conjugates. Australian Patent No. 691225 B2. Canberra, Australia: Australian Patent Office.

Glaesner, W., Vick, A. M., Millican, R., Ellis, B., Tschang, S. H., Tian, Y., et al. (2010). Engineering and Characterization of the Long-Acting Glucagon-like Peptide-1 Analogue LY2189265, an Fc Fusion Protein. Diabetes Metab. Res. Rev. 26, 287-296. doi:10.1002/dmrr.1080

Gottschalk, U., Brorson, K., and Shukla, A. A. (2012). The Need for Innovation in Biomanufacturing. Nat. Biotechnol. 30, 489-492. doi:10.1038/nbt.2263

Hagel, L., Östberg, M., and Andersson, T. (1996). Apparent Pore Size Distributions of Chromatography media. J. Chromatogr. A. 743, 33-42. doi:10.1016/00219673(96)00130-6

Hahn, R., Schlegel, R., and Jungbauer, A. (2003). Comparison of Protein A Affinity Sorbents. J. Chromatogr. B 790, 35-51. doi:10.1016/S1570-0232(03)00092-8

Hahn, R., Shimahara, K., Steindl, F., and Jungbauer, A. (2006). Comparison of Protein A Affinity Sorbents III. Life Time Study. J. Chromatogr. A. 1102, 224-231. doi:10.1016/j.chroma.2005.10.083

Hassett, B., Singh, E., Mahgoub, E., O'Brien, J., Vicik, S. M., and Fitzpatrick, B. (2018). Manufacturing History of Etanercept $\left(\right.$ Enbrel $\left.^{\circledR}\right)$ : Consistency of Product Quality through Major Process Revisions. MAbs 10, 159-165. doi:10.1080/19420862.2017.1388483

Havelund, S., Halstrom, J. B., Jonassen, I., Andersen, A. S., and Markussen, J. (1997). Acylated Insulin. Australian Patent No. 682061 B2. Canberra, Australia: Australian Patent Office.

Havelund, S., Plum, A., Ribel, U., Jonassen, I., Vølund, A., Markussen, et al. (2004). The Mechanism of Protraction of Insulin Detemir, A Long-Acting, Acylated Analog of Human Insulin. Pharm. Res. 21, 1498-1504. doi:10.1023/b: pham.0000036926.54824.37

Hernández-Martínez, A., and Aguilar, O. (2014). Chemical Grafting of Sepharose $6 \mathrm{~B}$ and its Use in the Purification of PEGylated RNase A. Sep. Purif. Technol. 136, 190-198. doi:10.1016/j.seppur.2014.09.005

Herzer, S., Bhangale, A., Barker, G., Chowdhary, I., Conover, M., O’Mara, B. W., et al. (2015). Development and Scale-Up of the Recovery and Purification of a Domain Antibody Fc Fusion Protein-Comparison of a Two and Three-step Approach. Biotechnol. Bioeng. 112, 1417-1428. doi:10.1002/bit.25561

Hou, Y., Brower, M., Pollard, D., Kanani, D., Jacquemart, R., Kachuik, B., et al. (2015). Advective Hydrogel Membrane Chromatography for Monoclonal Antibody Purification in Bioprocessing. Biotechnol. Prog. 31, 974-982. doi:10.1002/btpr.2113

Hoy, S. M. (2019). Pegfilgrastim-jmdb/MYL-1401H: A Pegfilgrastim Biosimilar. BioDrugs 33, 117-120. doi:10.1007/s40259-019-00334-9

Huang, Y., Zhai, Y., and Su, Z. (2013). "Microspheres for Separation of PEGModified Biomolecules," in Microspheres and Microcapsules in Biotechnology: Design, Preparation, and Applications. Editors G. Ma and Z. Su (New York: Pan Stanford Publishing), 183-202. doi:10.1201/b14540

Hubbuch, J., Linden, T., Knieps, E., Ljunglöf, A., Thömmes, J., and Kula, M. R. (2003). Mechanism and Kinetics of Protein Transport in Chromatographic media Studied by Confocal Laser Scanning Microscopy: Part I. The Interplay of Sorbent Structure and Fluid Phase Conditions. J. Chromatogr. A. 1021, 93-104. doi:10.1016/j.chroma.2003.08.112

Ingold, O., Pfister, D., and Morbidelli, M. (2016). A Reactive Continuous Chromatographic Process for Protein PEGylation. React. Chem. Eng. 1, 218-228. doi:10.1039/c5re00055f
Jafari, R., Zolbanin, N. M., Rafatpanah, H., Majidi, J., and Kazemi, T. (2017). Fcfusion Proteins in Therapy: An Updated View. Curr. Med. Chem. 24, 1228-1237. doi:10.2174/0929867324666170113112759

Jazayeri, J. A., and Carroll, G. J. (2008). Fc-Based Cytokines Prospects for Engineering Superior Therapeutics. BioDrugs 22, 11-26. doi:10.2165/ 00063030-200822010-00002

Jevševar, S., Kunstelj, M., and Porekar, V. G. (2010). PEGylation of Therapeutic Proteins. Biotechnol. J. 5, 113-128. doi:10.1002/biot.200900218

Jiang, C., Liu, J., Rubacha, M., and Shukla, A. A. (2009). A Mechanistic Study of Protein A Chromatography Resin Lifetime. J. Chromatogr. A. 1216, 5849-5855. doi:10.1016/j.chroma.2009.06.013

Jiang, H., Zhang, X., Chen, X., Aramsangtienchai, P., Tong, Z., and Lin, H. (2018). Protein Lipidation: Occurrence, Mechanisms, Biological Functions, and Enabling Technologies. Chem. Rev. 118, 919-988. doi:10.1021/ acs.chemrev.6b00750

Jin, P., Niu, J., Lei, J., and Juncai, W. (2012). Medicine Containing Peg Human Growth Hormone Conjugate and Use Thereof. China Patent No. 101491681 B. Beijing, China: China National Intellectual Property Administration.

Jonassen, I., Hoeg-Jensen, T., Havelund, S., Ribel-Madsen, U., Tagmose, T. M., and Madsen, P. (2009). Insulin Derivatives. U.S. Patent No. 7615532 B2. Washington, DC: U.S. Patent and Trademark Office.

Jonassen, I., Havelund, S., Hoeg-Jensen, T., Steensgaard, D. B., Wahlund, P. O., and Ribel, U. (2012). Design of the Novel Protraction Mechanism of Insulin Degludec, an Ultra-long-acting Basal Insulin. Pharm. Res. 29, 2104-2114. doi:10.1007/s11095-012-0739-z

Josic, D., and Kovac, S. (2010). Reversed-phase High Performance Liquid Chromatography of Proteins. Curr. Protoc. Protein Sci. 61, 8.7.1-8.7.22. doi:10.1002/0471140864.ps0807s61

Joucla, G., Le Sénéchal, C., Bégorre, M., Garbay, B., Santarelli, X., and Cabanne, C. (2013). Cation Exchange versus Multimodal Cation Exchange Resins for Antibody Capture from CHO Supernatants: Identification of Contaminating Host Cell Proteins by Mass Spectrometry. J. Chromatogr. B: Anal. Technol. Biomed. Life Sci. 942-943, 126-133. doi:10.1016/j.jchromb.2013.10.033

Jungbauer, A., and Hahn, R. (2008). Polymethacrylate Monoliths for Preparative and Industrial Separation of Biomolecular Assemblies. J. Chromatogr. A. 1184, 62-79. doi:10.1016/j.chroma.2007.12.087

Jungbauer, A. (2005). Chromatographic media for Bioseparation. J. Chromatogr. A. 1065, 3-12. doi:10.1016/j.chroma.2004.08.162

Kaleas, K. A., Tripodi, M., Revelli, S., Sharma, V., and Pizarro, S. A. (2014). Evaluation of a Multimodal Resin for Selective Capture of CHO-Derived Monoclonal Antibodies Directly from Harvested Cell Culture Fluid. J. Chromatogr. B: Anal. Technol. Biomed. Life Sci. 969, 256-263. doi:10.1016/j.jchromb.2014.08.026

Karasiewicz, R., Carlo, N., and Perry, R. (1995). Peg-interferon Conjugates. U.S. Patent No. 5382657 A. Washington, DC: U.S. Patent and Trademark Office.

Knudsen, L. B., and Lau, J. (2019). The Discovery and Development of Liraglutide and Semaglutide. Front. Endocrinol. 10, 155. doi:10.3389/fendo.2019.00155

Knudsen, L. B., Huusfeldt, P. O., Nielsen, P. F., Kaarsholm, N. C., Olsen, H. B., Bjoern, S. E., et al. (2001). Derivatives of GLP-1 Analogs. U.S. Patent No. 6268343 B1. Washington, DC: U.S. Patent and Trademark Office.

Kohn, W. D., Micanovic, R., Myers, S. L., Vick, A. M., Kahl, S. D., Zhang, L., et al. (2007). pI-Shifted Insulin Analogs with Extended In Vivo Time Action and Favorable Receptor Selectivity. Peptides 28, 935-948. doi:10.1016/ j.peptides.2007.01.012

Kratz, F. (2008). Albumin as a Drug Carrier: Design of Prodrugs, Drug Conjugates and Nanoparticles. J. Control Release 132, 171-183. doi:10.1016/ j.jconrel.2008.05.010

Kurtzhals, P., Havelund, S., Jonassen, I., Kiehr, B., Larsen, U. D., Ribel, U., et al. (1995). Albumin Binding of Insulins Acylated with Fatty Acids: Characterization of the Ligand-Protein Interaction and Correlation between Binding Affinity and Timing of the Insulin Effect In Vivo. Biochem. J. 312, 725-731. doi:10.1042/bj3120725

Lagassé, H. A. D., Alexaki, A., Simhadri, V. L., Katagiri, N. H., Jankowski, W., Sauna, Z. E., et al. (2017). Recent Advances in (Therapeutic Protein) Drug Development. F1000research 6, 113. doi:10.12688/f1000research.9970.1

Lau, J., Bloch, P., and Hansen, T. K. (2012). Acylated GLP-1 Compounds. U.S. Patent No. 8129343 B2. Washington, DC: U.S. Patent and Trademark Office. 
Lee, M.-H., Lin, Y.-S., Tu, C.-F., and Yen, C.-H. (2014). Recombinant Human Factor IX Produced from Transgenic Porcine Milk. Biomed. Res. Int. 2014, 1-8. doi:10.1155/2014/315375

Leister, K., Schaefer, E. J., Bates, R., Bramhall, E. A., Didio, D. M., Donaldson, R., et al. (2010). Compositions and Methods for Producing a Composition. European Patent No. 2253644 A1. Munich, Germany: European Patent Office.

Levison, P. R., Jones, R. M. H., Toome, D. W., Badger, S. E., Streater, M., and Pathirana, N. D. (1996). Influence of Flow-Rate on the Chromatographic Performance of Agarose- and Cellulose-Based Anion-Exchange media. J. Chromatogr. A. 734, 137-143. doi:10.1016/0021-9673(95)00850-0

Li, C., and Wang, L.-X. (2018). Chemoenzymatic Methods for the Synthesis of Glycoproteins. Chem. Rev. 118, 8359-8413. doi:10.1021/acs.chemrev.8b00238

Li, Y. (2017). Effective Strategies for Host Cell Protein Clearance in Downstream Processing of Monoclonal Antibodies and Fc-Fusion Proteins. Protein Expres. Purif. 134, 96-103. doi:10.1016/j.pep.2017.04.006

Lin, K.-C., and Widmann, R. (2013). Therapeutic Use of Interferon-Polymer Conjugates. U.S. Patent No. 8617532 B2. Washington, DC: U.S. Patent and Trademark Office.

Lingg, N., Zhang, P., Song, Z., and Bardor, M. (2012). The Sweet Tooth of Biopharmaceuticals: Importance of Recombinant Protein Glycosylation Analysis. Biotechnol. J. 7, 1462-1472. doi:10.1002/biot.201200078

Linsley, P. S., Ledbetter, J. A., Damle, N. K., and Brady, W. (1998). CTLA4 Ig Fusion Proteins. U.S. Patent No. 5844095 A. Washington, DC: U.S. Patent and Trademark Office.

Liu, H. F., Ma, J., Winter, C., and Bayer, R. (2010). Recovery and Purification Process Development for Monoclonal Antibody Production. MAbs 2, 480-499. doi:10.4161/mabs.2.5.12645

Liu, L., Gomathinayagam, S., Hamuro, L., Prueksaritanont, T., Wang, W., Stadheim, T. A., et al. (2013). The Impact of Glycosylation on the Pharmacokinetics of a TNFR2:Fc Fusion Protein Expressed in Glycoengineered Pichia Pastoris. Pharm. Res. 30, 803-812. doi:10.1007/ s11095-012-0921-3

Liu, C.-F., Feige, U., and Cheetham, J. C. (2017). Thrombopoietic Compounds. U.S. Patent No. 9534032 B2. Washington, DC: U.S. Patent and Trademark Office.

Lloyd, I. (2018). Data from: Pharma R \& D Annual Review 2018. London, England: Pharma Intelligence. Available at: https://pharmaintelligence.informa.com/ resources/product-content/pharma-rd-annual-review-2018 (Accesed September 23, 2020).

Longo, E., Santis, E. D., Hussain, R., Van Der Walle, C. F., Casas-Finet, J., Uddin, S., et al. (2014). The Effect of Palmitoylation on the Conformation and Physical Stability of a Model Peptide Hormone. Int. J. Pharm. 472, 156-164. doi:10.1016/ j.ijpharm.2014.06.008

Maiser, B., Baumgartner, K., Dismer, F., and Hubbuch, J. (2015). Effect of Lysozyme Solid-phase PEGylation on Reaction Kinetics and Isoform Distribution. J. Chromatogr. B 1002, 313-318. doi:10.1016/ j.jchromb.2015.08.027

Mannucci, P. M., and Franchini, M. (2014). Emerging Drugs for Hemophilia B. Expert Opin. Emerg. Drugs 19, 407-414. doi:10.1517/14728214.2014.946010

Mant, C. T., and Hodges, R. S. (1991). "The Use of Peptide Standards for Monitoring Ideal and Non-ideal Behavior in Cation-Exchange Chromatography," in High-Performance Liquid Chromatography of Peptides and Proteins Separation, Analysis, and Conformation. Editors T. ColinMant and R. S. Hodges (Boca Raton: CRC Press). doi:10.1201/9780203751947

Marini, B. L., Perissinotti, A. J., Bixby, D. L., Brown, J., and Burke, P. W. (2017). Catalyzing Improvements in ALL Therapy with Asparaginase. Blood Rev. 31, 328-338. doi:10.1016/j.blre.2017.06.002

Matlschweiger, A., Fuks, P., Carta, G., and Hahn, R. (2019). Hindered Diffusion of Proteins in Mixture Adsorption on Porous Anion Exchangers and Impact on Flow-Through Purification of Large Proteins. J. Chromatogr. A. 1585, 121-130. doi:10.1016/j.chroma.2018.11.060

Mayolo-Deloisa, K., Lienqueo, M. E., Andrews, B., Rito-Palomares, M., and Asenjo, J. A. (2012). Hydrophobic Interaction Chromatography for Purification of monoPEGylated RNase A. J. Chromatogr. A. 1242, 11-16. doi:10.1016/ j.chroma.2012.03.079

Mayolo-Deloisa, K., González-Valdez, J., and Rito-Palomares, M. (2016). PEGylated Protein Separation Using Different Hydrophobic Interaction Supports: Conventional and Monolithic Supports. Biotechnol. Progr. 32, 702-707. doi:10.1002/btpr.2254
McCue, J., Osborne, D., Dumont, J., Peters, R., Mei, B., Pierce, G. F., et al. (2014). Validation of the Manufacturing Process Used to Produce Long-Acting Recombinant Factor IX Fc Fusion Protein. Haemophilia 20, 1-9. doi:10.1111/hae.12451

McCue, J., Kshirsagar, R., Selvitelli, K., Lu, Q., Zhang, M., Mei, B., et al. (2015). Manufacturing Process Used to Produce Long-Acting Recombinant Factor VIII Fc Fusion Protein. Biologicals 43, 213-219. doi:10.1016/ j.biologicals.2015.05.012

Mei, B., Pan, C., Jiang, H., Tjandra, H., Strauss, J., Chen, Y., et al. (2010). Rational Design of a Fully Active, Long-Acting PEGylated Factor VIII for Hemophilia A Treatment. Blood 116, 270-279. doi:10.1182/blood-2009-11-254755

Mejía-Manzano, L. A., Lienqueo, M. E., Escalante-Vázquez, E. J., Rito-Palomares, M., and Asenjo, J. A. (2017). Optimized Purification of Mono-PEGylated Lysozyme by Heparin Affinity Chromatography Using Response Surface Methodology. J. Chem. Technol. Biotechnol. 92, 2554-2562. doi:10.1002/ jctb.5269

Metzner, H. J., Weimer, T., Kronthaler, U., Lang, W., and Schulte, S. (2009). Genetic Fusion to Albumin Improves the Pharmacokinetic Properties of Factor IX. Thromb. Haemost. 102, 634-644. doi:10.1160/TH09-04-0255

Miller, G. T., Hochman, P. S., Meier, W., Tizard, R., Bixler, S. A., Rosa, M. D., et al. (1993). Specific Interaction of Lymphocyte Function-Associated Antigen 3 with CD2 Can Inhibit T Cell Responses. J. Exp. Med. 178, 211-222. doi:10.1084/ jem.178.1.211

Miyabe, K., and Guiochon, G. (2000). Kinetic Study of the Mass Transfer of Bovine Serum Albumin in Anion-Exchange Chromatography. J. Chromatogr. A. 866, 147-171. doi:10.1016/S0021-9673(99)01127-9

Mohler, K. M., Torrance, D. S., Smith, C. A., Goodwin, R. G., Stremler, K. E., Fung, V. P., et al. (1993). Soluble Tumor Necrosis Factor (TNF) Receptors Are Effective Therapeutic Agents in Lethal Endotoxemia and Function Simultaneously as Both TNF Carriers and TNF Antagonists. J. Immunol. $151,1548-1561$.

Molek, J. R., and Zydney, A. L. (2006). Ultrafiltration Characteristics of Pegylated Proteins. Biotechnol. Bioeng. 95, 474-482. doi:10.1002/bit.21020

Molineux, G. (2004). The Design and Development of Pegfilgrastim (PEGrmetHuG-CSF, Neulasta ${ }^{\circledR}$ ). Curr. Pharm. Des. 10, 1235-1244. doi:10.2174/ 1381612043452613

Moorkens, E., Meuwissen, N., Huys, I., Declerck, P., Vulto, A. G., and Simoens, S. (2017). The Market of Biopharmaceutical Medicines: A Snapshot of a Diverse Industrial Landscape. Front. Pharmacol. 8, 314. doi:10.3389/fphar.2017.00314

Morfini, M., and Zanon, E. (2016). Emerging Drugs for the Treatment of Hemophilia A and B. Expert Opin. Emerg. Drugs 21, 301-313. doi:10.1080/ 14728214.2016.1220536

Nguyen, N. T. T., Lee, J. S., Yun, S., and Lee, E. K. (2016). Separation of Mono- and Di-PEGylate of Exenatide and Resolution of Positional Isomers of MonoPEGylates by Preparative Ion Exchange Chromatography. J. Chromatogr. A. 1457, 88-96. doi:10.1016/j.chroma.2016.06.035

Nweke, M. C., McCartney, R. G., and Bracewell, D. G. (2017). Mechanical Characterisation of Agarose-Based Chromatography Resins for Biopharmaceutical Manufacture. J. Chromatogr. A. 1530, 129-137. doi:10.1016/j.chroma.2017.11.038

Olson, K., Gehant, R., Mukku, V., O'Connell, K., Tomlinson, B., Totpal, K., et al. (1997). "Preparation and Characterization of Poly(ethylene Glycol)ylated Human Growth Hormone Antagonist," in Poly(ethylene Glycol) Chemistry and Biological Applications. Editors J. M. Harris and S. Zalipsky (Washington, DC: American Chemical Society), 170-181. doi:10.1021/bk-1997-0680.ch012:

Orr, V., Zhong, L., Moo-Young, M., and Chou, C. P. (2013). Recent Advances in Bioprocessing Application of Membrane Chromatography. Biotechnol. Adv. 31, 450-465. doi:10.1016/j.biotechadv.2013.01.007

Pabst, T. M., and Carta, G. (2007). pH Transitions in Cation Exchange Chromatographic Columns Containing Weak Acid Groups. J. Chromatogr. A. 1142, 19-31. doi:10.1016/j.chroma.2006.08.066

Pabst, T. M., Buckley, J. J., Ramasubramanyan, N., and Hunter, A. K. (2007). Comparison of strong Anion-Exchangers for the Purification of a PEGylated Protein. J. Chromatogr. A. 1147, 172-182. doi:10.1016/j.chroma.2007.02.051

Pabst, T. M., Antos, D., Carta, G., Ramasubramanyan, N., and Hunter, A. K. (2008). Protein Separations with Induced $\mathrm{pH}$ Gradients Using CationExchange Chromatographic Columns Containing Weak Acid Groups. J. Chromatogr. A. 1181, 83-94. doi:10.1016/j.chroma.2007.12.054 
Papathanasiou, M. M., and Kontoravdi, C. (2020). Engineering Challenges in Therapeutic Protein Product and Process Design. Curr. Opin. Chem. Eng. 27, 81-88. doi:10.1016/j.coche.2019.11.010

Park, E. J., Choi, J., Lee, K. C., and Na, D. H. (2019). Emerging PEGylated Nonbiologic Drugs. Expert Opin. Emerg. Drugs 24, 107-119. doi:10.1080/ 14728214.2019.1604684

Pelegri-O'Day, E. M., Lin, E., and Maynard, H. D. (2014). Therapeutic Protein Polymer Conjugates: Advancing beyond PEGylation. J. Am. Chem. Soc. 136, 14323-14332. doi:10.1021/ja504390x

Pepinsky, R. B., Lepage, D. J., Gill, A., Chakraborty, A., Vaidyanathan, S., Green, M., et al. (2001). Improved Pharmacokinetic Properties of a Polyethylene Glycol-Modified Form of Interferon- $\beta-1 \mathrm{a}$ with Preserved In Vitro Bioactivity. J. Pharmacol. Exp. Ther. 297, 1059-1066.

Pepinsky, B., Runkel, L., Brickelmaier, M., Whitty, A., and Hochman, P. (2005). Polymer Conjugates of Interferon Beta-1a and Uses. U.S. Patent No. 6962978 B2. Washington, DC, United States: U.S. Patent and Trademark Office.

Peters, R. T., Low, S. C., Kamphaus, G. D., Dumont, J. A., Amari, J. V., Lu, Q., et al. (2010). Prolonged Activity of Factor IX as a Monomeric Fc Fusion Protein. Blood 115, 2057-2064. doi:10.1182/blood-2009-08-239665

Pezzini, J., Joucla, G., Gantier, R., Toueille, M., Lomenech, A.-M., Le Sénéchal, C., et al. (2011). Antibody Capture by Mixed-Mode Chromatography: A Comprehensive Study from Determination of Optimal Purification Conditions to Identification of Contaminating Host Cell Proteins. J. Chromatogr. A. 1218, 8197-8208. doi:10.1016/j.chroma.2011.09.036

Pfister, D., and Morbidelli, M. (2014). Process for Protein PEGylation. J. Control Release 180, 134-149. doi:10.1016/j.jconrel.2014.02.002

Pfister, D., Ingold, O., and Morbidelli, M. (2016). Model-based Development of an On-Column PEGylation Process. React. Chem. Eng. 1, 204-217. doi:10.1039/ C5RE00019J

Pinto, I. F., Aires-Barros, M. R., and Azevedo, A. M. (2015). Multimodal Chromatography: Debottlenecking the Downstream Processing of Monoclonal Antibodies. Pharm. Bioproc. 3, 263-279. doi:10.4155/pbp.15.7

Pisal, D. S., Kosloski, M. P., and Balu-Iyer, S. V. (2010). Delivery of Therapeutic Proteins. J. Pharm. Sci. 99, 2557-2575. doi:10.1002/jps.22054

Poole, C. F., and Lenca, N. (2017). "Reversed-phase Liquid Chromatography," in Liquid Chromatography Fundamentals and Instrumentation. Editors S. Fanali, P. R. Haddad, C. F. Poole, and M.-L. B. T. Riekkola (Amsterdam, Netherlands: Elsevier), 91-123. doi:10.1016/B978-0-12-805393-5.00004-X:

Premsukh, A., Lavoie, J. M., Cizeau, J., Entwistle, J., and MacDonald, G. C. (2011). Development of a GMP Phase III Purification Process for VB4-845, an Immunotoxin Expressed in E. coli Using High Cell Density Fermentation. Protein Expr. Purif. 78, 27-37. doi:10.1016/j.pep.2011.03.009

Przybycien, T. M., Pujar, N. S., and Steele, L. M. (2004). Alternative Bioseparation Operations: Life beyond Packed-Bed Chromatography. Curr. Opin. Biotechnol. 15, 469-478. doi:10.1016/j.copbio.2004.08.008

Qu, J.-B., Zhou, W.-Q., Wei, W., Su, Z.-G., and Ma, G.-H. (2008). An Effective Way to Hydrophilize Gigaporous Polystyrene Microspheres as Rapid Chromatographic Separation Media for Proteins. Langmuir 24, 13646-13652. doi:10.1021/la801486t

Ramos-de-la-Peña, A. M., and Aguilar, O. (2020). Progress and Challenges in PEGylated Proteins Downstream Processing: A Review of the Last 8 Years. Int. J. Pept. Res. Ther. 26, 333-348. doi:10.1007/s10989-019-09840-4

Ramos-de-la-Peña, A. M., González-Valdez, J., and Aguilar, O. (2019). Protein A Chromatography: Challenges and Progress in the Purification of Monoclonal Antibodies. J. Sep. Sci. 42, 1816-1827. doi:10.1002/jssc.201800963

Rath, T., Baker, K., Dumont, J. A., Peters, R. T., Jiang, H., Qiao, S. W., et al. (2015). Fc-fusion Proteins and FcRn: Structural Insights for Longer Lasting and More Effective therapeutics.Crit. Rev. Biotechnol. 35, 235-254. doi:10.3109/ 07388551.2013.834293

Rathore, A. S., Kumar, D., and Kateja, N. (2018). Recent Developments in Chromatographic Purification of Biopharmaceuticals. Biotechnol. Lett. 40, 895-905. doi:10.1007/s10529-018-2552-1

Research and Markets. (2021). Therapeutic Proteins Global Market Report 2021: COVID-19 Impact and Recovery to 2030. https://www.researchandmarkets. com/reports/5319142/therapeutic-proteins-global-market-report-2021. (Accessed August 28, 2021)

Resh, M. D. (2013). Covalent Lipid Modifications of Proteins. Curr. Biol. 23, R431-R435. doi:10.1016/j.cub.2013.04.024
Roucka, M., Zimmermann, K., and Fido, M. (2018). Glycosylation Pattern of Biotechnologically Produced Proteins - Lectin Array Technology as a Versatile Tool for Screening?. Med. Res. Arch. 6. doi:10.18103/mra.v6i3.1698

Sánchez-Trasviña, C., Rito-Palomares, M., and González-Valdez, J. (2019). Development and Characterization of PEGylated Chromatographic Monoliths as a Novel Platform for the Separation of PEGylated RNase a Isomers. Adv. Polym. Technol. 2019, 1-10. doi:10.1155/2019/5067028

Sako, D., Grinberg, A. V., Liu, J., Davies, M. V., Castonguay, R., Maniatis, S., et al. (2010). Characterization of the Ligand Binding Functionality of the Extracellular Domain of Activin Receptor Type IIB. J. Biol. Chem. 285, 21037-21048. doi:10.1074/jbc.M110.114959

Santagostino, E., Negrier, C., Klamroth, R., Tiede, A., Pabinger-Fasching, I., Voigt, C., et al. (2012). Safety and Pharmacokinetics of a Novel Recombinant Fusion Protein Linking Coagulation Factor IX with Albumin (rIX-FP) in Hemophilia B Patients. Blood 120, 2405-2411. doi:10.1182/blood-2012-05-429688

Schlüter, H. (1999). "Reversed-Phase Chromatography," in Protein Liquid Chromatography. Editor C. L. Kastner (Amsterdam, Netherlands: Elsevier), 147-234. doi:10.1016/S0301-4770(08)60531-X

Schmitt, M. G., Rajendra, Y., Hougland, M. D., Boyles, J. S., and Barnard, G. C. (2017). Polymer-mediated Flocculation of Transient CHO Cultures as a Simple, High Throughput Method to Facilitate Antibody Discovery. Biotechnol. Prog. 33, 1393-1400. doi:10.1002/btpr.2527

Seely, J. E., and Richey, C. W. (2001). Use of Ion-Exchange Chromatography and Hydrophobic Interaction Chromatography in the Preparation and Recovery of Polyethylene Glycol-Linked Proteins. J. Chromatogr. A. 908, 235-241. doi:10.1016/S0021-9673(00)00739-1

Sherman, M. R., David Williams, L., Saifer, M. G. P., French, J. A., Kwak, L. W., and Oppenheim, J. J. (1997). "Conjugation of High-Molecular Weight Poly(ethylene Glycol) to Cytokines: Granulocyte-Macrophage ColonyStimulating Factors as Model Substrates," in Poly(ethylene Glycol) Chemistry and Biological Applications. Editors J. M. Harris and S. Zalipsky (Washington, DC: American Chemical Society), 155-169. doi:10.1021/bk-1997-0680.ch011

Sherman, M. R., Saifer, M. G. P., and Williams, L. D. (2004). Aggregate-free Urate Oxidase for Preparation of Non-immunogenic Polymer Conjugates. U.S. Patent No. 6783965 B1. Washington, DC, United States: U.S. Patent and Trademark Office.

Shi, Q. H., Zhou, X., and Sun, Y. (2005). A Novel Superporous Agarose Medium for High-Speed Protein Chromatography. Biotechnol. Bioeng. 92, 643-651. doi:10.1002/bit.20652

Shukla, A. A., and Aranha, H. (2015). Viral Clearance for Biopharmaceutical Downstream Processes. Pharm. Bioproc. 3, 127-138. doi:10.4155/pbp.14.62

Shukla, A. A., and Gottschalk, U. (2013). "Downstream Processing of Fc-Fusion Proteins," in Therapeutic Fc-Fusion Proteins. Editors S. M. Chamow, T. Ryll, H. B. Lowman, and D. Farson (Weinheim, Germany: Wiley-VCH Verlag), 97-114. doi:10.1002/9783527675272.ch04

Shukla, A. A., and Norman, C. L. (2017). "Downstream Processing of Fc Fusion Proteins, Bispecific Antibodies, and Antibody-Drug Conjugates," in Process Scale Purification of Antibodies. Editor U. Gottschalk (Hoboken, NJ: John Wiley \& Sons), 559-594. doi:10.1002/9781119126942.ch26

Shukla, A. A., and Thömmes, J. (2010). Recent Advances in Large-Scale Production of Monoclonal Antibodies and Related Proteins. Trends Biotechnol. 28, 253-261. doi:10.1016/j.tibtech.2010.02.001

Shukla, A. A., Hubbard, B., Tressel, T., Guhan, S., and Low, D. (2007). Downstream Processing of Monoclonal Antibodies-Application of Platform Approaches. J. Chromatogr. B Analyt. Technol. Biomed. Life Sci. 848, 28-39. doi:10.1016/ j.jchromb.2006.09.026

Shukla, A. A., Wolfe, L. S., Mostafa, S. S., and Norman, C. (2017). Evolving Trends in mAb Production Processes. Bioeng. Transl. Med. 2, 58-69. doi:10.1002/ btm2.10061

Siekmann, J., Martin, P., Zöchling, O., Kellerer, R., Rottensteiner, H., Mitterer, A., et al. (2011). Development of a Large Scale Production Process for BAX 855, a PEGylated rFVIII Product with Prolonged Half-Life. Blood 118, 4362. doi:10.1182/blood.V118.21.4362.4362

Silva, L., Plewka, G., Lichtenegger, H., Dias-Cabral, A. C., Jungbauer, A., and Tscheließnig, R. (2018). The Pearl Necklace Model in Protein A Chromatography: Molecular Mechanisms at the Resin Interface. Biotechnol. Bioeng. 116, 76-86. doi:10.1002/bit.26843 
Sleep, D., Cameron, J., and Evans, L. R. (2013). Albumin as a Versatile Platform for Drug Half-Life Extension. Biochim. Biophys. Acta 1830, 5526-5534. doi:10.1016/j.bbagen.2013.04.023

Solá, R. J., and Griebenow, K. (2010). Glycosylation of Therapeutic Proteins: An Effective Strategy to Optimize Efficacy. BioDrugs 24, 9-21. doi:10.2165/ 11530550-000000000-00000

Staahlberg, J., Joensson, B., and Horvath, C. (1991). Theory for Electrostatic Interaction Chromatography of Proteins. Anal.l Chem. 63, 1867-1874. doi:10.1021/ac00017a 036

Staby, A., Nielsen, J., Krarup, J., Wiendahl, M., Hansen, T., Kidal, S., et al. (2009). "Advances in Resins for Ion-Exchange Chromatography," in Advances in Chromatography. Editors E. Grushka and N. Grinberg (Boca Raton: CRC Press), 193-245. doi:10.1201/9781420060379.ch6:

Staby, A. (2011). Ion Exchange Chromatography of GLP-1, Analogs and Derivatives Thereof. U.S. Patent No. 8067554 B2. Washington, DC, United States: U.S. Patent and Trademark Office.

Stennicke, H. R., Østergaard, H., Bayer, R. J., Kalo, M. S., Kinealy, K., Holm, P. K., et al. (2008). Generation and Biochemical Characterization of glycoPEGylated Factor VIIa Derivatives. Thromb. Haemost. 100, 920-928. doi:10.1160/TH0804-0268

Stennicke, H. R., Kjalke, M., Karpf, D. M., Balling, K. W., Johansen, P. B., Elm, T., et al. (2013). A Novel B-Domain O-glycoPEGylated FVIII (N8-GP) Demonstrates Full Efficacy and Prolonged Effect in Hemophilic Mice Models. Blood 121, 2108-2116. doi:10.1182/blood-2012-01-407494

Strohl, W. R. (2015). Fusion Proteins for Half-Life Extension of Biologics as a Strategy to Make Biobetters. BioDrugs 29, 215-239. doi:10.1007/s40259-015-0133-6

Swierczewska, M., Lee, K. C., and Lee, S. (2015). What Is the Future of PEGylated Therapies?. Expert Opin. Emerg. Drugs 20, 531-536. doi:10.1517/14728214.2015.1113254

Thygesen, P., Andersen, H. S., Behrens, C., Fels, J. J., Nørskov-Lauritsen, L., Rischel, C., et al. (2017). Nonclinical Pharmacokinetic and Pharmacodynamic Characterisation of Somapacitan: A Reversible Non-covalent AlbuminBinding Growth Hormone. Growth Horm. IGF Res. 35, 8-16. doi:10.1016/ j.ghir.2017.05.006

Tihanyi, B., and Nyitray, L. (2021). Recent Advances in CHO Cell Line Development for Recombinant Protein Production. Drug Discov. Today Technol. doi:10.1016/j.ddtec.2021.02.003

Toueille, M., Uzel, A., Depoisier, J.-F., and Gantier, R. (2011). Designing New Monoclonal Antibody Purification Processes Using Mixed-Mode Chromatography Sorbents. J. Chromatogr. B 879, 836-843. doi:10.1016/ j.jchromb.2011.02.047

Turecek, P. L., Bossard, M. J., Graninger, M., Gritsch, H., Höllriegl, W., Kaliwoda, M., et al. (2012). BAX 855, a PEGylated rFVIII Product with Prolonged HalfLife. Hamostaseologie 32, S29-S38. doi:10.1055/s-0037-1619772

Turecek, P. L., Bossard, M. J., Schoetens, F., and Ivens, I. A. (2016). PEGylation of Biopharmaceuticals: A Review of Chemistry and Nonclinical Safety Information of Approved Drugs. J. Pharm. Sci. 105, 460-475. doi:10.1016/ j.xphs.2015.11.015

van Witteloostuijn, S. B., Pedersen, S. L., and Jensen, K. J. (2016). Half-Life Extension of Biopharmaceuticals Using Chemical Methods: Alternatives to PEGylation. ChemMedChem 11, 2474-2495. doi:10.1002/cmdc.201600374

Vaniotis, G., Moffett, S., Sulea, T., Wang, N., Elahi, S. M., Lessard, E., et al. (2018). Enhanced Anti-metastatic Bioactivity of an IGF-TRAP Re-engineered to Improve Physicochemical Properties. Sci. Rep. 8, 17361. doi:10.1038/s41598018-35407-2

Vellard, M. C., Fitzpatrick, P. A., Kakkis, E. D., and Wendt, D. J. (2008). Compositions of Prokaryotic Phenylalanine Ammonia-Lyase and Methods of Using Said Compositions. World Patent No.2008/153776 A1. Geneva, Switzerland: World Intellectual Property Organization.

Veronese, F. M., and Pasut, G. (2007). "Drug-Polymer Conjugates," in Comprehensive Medicinal Chemistry II. Editors J. B. Taylor and D. J. Triggle (Elsevier Science), 1043-1068. doi:10.1016/B0-08-045044-X/00159-0

Vreeker, G. C. M., and Wuhrer, M. (2017). Reversed-phase Separation Methods for Glycan Analysis. Anal. Bioanal. Chem. 409, 359-378. doi:10.1007/s00216-0160073-0

Wallner, B. P., Miller, G. T., and Rosa, M. D. (1999). Method of Using CD2-Binding Domain of Lymphocyte Function Associated Antigen 3 to Initiate T Cell Activation. U.S. Patent No. 5928643 A. Washington, DC, United States: U.S. Patent and Trademark Office.
Walsh, G. (2018). Biopharmaceutical Benchmarks 2018. Nat. Biotechnol. 36, 1136-1145. doi:10.1038/nbt.4305

Wang, Y., and Carta, G. (2019). Competitive Binding of Monoclonal Antibody Monomer-Dimer Mixtures on Ceramic Hydroxyapatite. J. Chromatogr. A. 1587, 136-145. doi:10.1016/j.chroma.2018.12.023

Wang, J., Shen, D., and Shen, W.-C. (1999). Preparation, Purification, and Characterization of a Reversibly Lipidized Desmopressin with Potentiated Anti-diuretic Activity. Pharm. Res. 16 (11), 1674-1679. doi:10.1023/A: 1018929312715

Wang, F., Surh, J., and Kaur, M. (2012). Insulin Degludec as an Ultralong-Acting Basal Insulin once a Day: a Systematic Review. Diabetes Metab. Syndr. Obes. Targets Ther. 5, 191-204. doi:10.2147/DMSO.S21979

Wang, X., Li, X., Zhao, J., Lv, L., Qin, K., Yuan, H., et al. (2017). In Situ PEGylation of Recombinant Hirudin on an Anion Exchange Chromatography Column. Process. Biochem. 55, 162-171. doi:10.1016/j.procbio.2017.01.024

Weiss, J. (2019). "Gradient Elution of Ionic Compounds," in Gradient HPLC for Practitioners. Editor S. Kromidas (Weinheim, Germany: John Wiley \& Sons), 113-159. doi:10.1002/9783527812745.ch4

Wetterhall, M., Ander, M., Björkman, T., Musunuri, S., and Palmgren, R. (2021). Investigation of Alkaline Effects on Protein A Affinity Ligands and Resins Using High Resolution Mass Spectrometry. J. Chromatogr. B 1162, 122473. doi:10.1016/j.jchromb.2020.122473

Wiendahl, M. K. D., Sejersgaard, L., and Bogsnes, A. (2020). Method of Purifying Pegylated Proteins. European Patent No. 2504349 B1. Munich, Germany: European Patent Office.

Williams, L. D., Hershfield, M. S., Kelly, S. J., Saifer, M. G. P., and Sherman, M. R. (2003). Peg-urate Oxidase Conjugates and Use Thereof. U.S. Patent No. 6576235 B1. Washington, DC, United States: U.S. Patent and Trademark Office.

Xiong, S., Zhang, L., and He, Q.-Y. (2008). "Fractionation of Proteins by Heparin Chromatography BT - 2D PAGE: Sample Preparation and Fractionation," in Methods in Molecular Biology. Editor A. Posch (TotowaNJ: Humana Press), 213-221. doi:10.1007/978-1-60327-064-9_18

Xu, X., Didio, D. M., Leister, K. J., and Ghose, S. (2010). Disaggregation of HighMolecular Weight Species during Downstream Processing to Recover Functional Monomer. Biotechnol. Prog. 26, 717-726. doi:10.1002/btpr.373

Yan, S. B. (1996). Review of Conformation-specific Affinity Purification Methods for Plasma Vitamin K-dependent Proteins. J. Mol. Recognit. 9, 211-218. doi:10.1002/(sici)1099-1352(199605)9:3<211::aid-jmr334>3.0.co;2-7

Yang, C., Gao, X., and Gong, R. (2018). Engineering of Fc Fragments with Optimized Physicochemical Properties Implying Improvement of Clinical Potentials for FcBased Therapeutics. Front. Immunol. 8, 1860. doi:10.3389/fimmu.2017.01860

Yang, J., Liu, R., Granghaud, A., Zaidi, O., and Stephens, J. (2021). Biosimilar Pegfilgrastim May Offer Affordable Treatment Options for Patients in France: a Budget Impact Analysis on the Basis of Clinical Trial and Real-World Data. J. Med. Econ. 24, 665-674. doi:10.1080/13696998.2021.1922252

Yao, Y., and Lenhoff, A. M. (2004). Determination of Pore Size Distributions of Porous Chromatographic Adsorbents by Inverse Size-Exclusion Chromatography. J. Chromatogr. A. 1037, 273-282. doi:10.1016/j.chroma.2004.02.054

Yao, Y., and Lenhoff, A. M. (2006). Pore Size Distributions of Ion Exchangers and Relation to Protein Binding Capacity. J. Chromatogr. A. 1126, 107-119. doi:10.1016/j.chroma.2006.06.057

Yuan, L., Wang, J., and Shen, W.-C. (2008). Lipidization of Human InterferonAlpha: A New Approach toward Improving the Delivery of Protein Drugs. J. Control Release 129, 11-17. doi:10.1016/j.jconrel.2008.03.014

Zalipsky, S., and Pasut, G. (2020). "Evolution of Polymer Conjugation to Proteins," in Polymer-Protein Conjugates from PEGylation and beyond. Editors G. Pasut and S. Zalipsky (Amsterdam, Netherlands: Elsevier), 3-22. doi:10.1016/b978-0444-64081-9.00001-2:

Zhai, Y., Zhou, W., Wei, W., Qu, J., Lei, J., Su, Z., et al. (2012). Functional Gigaporous Polystyrene Microspheres Facilitating Separation of Poly(ethylene Glycol)-Protein Conjugate. Anal. Chim. Acta 712, 152-161. doi:10.1016/ j.aca.2011.11.004

Zhang, P., Woen, S., Wang, T., Liau, B., Zhao, S., Chen, C., et al. (2016). Challenges of Glycosylation Analysis and Control: An Integrated Approach to Producing Optimal and Consistent Therapeutic Drugs. Drug Discov. Today 21, 740-765. doi:10.1016/j.drudis.2016.01.006

Zhou, T., Wang, L., Zhang, Z., and Jin, M. (2019). An Enhanced Regeneration Strategy to Improve Microbial Control and Prolong Resin Lifetime for Protein 
A Resin in Large-Scale Monoclonal Antibody (mAb) Purification. J. Biotechnol. 289, 118-125. doi:10.1016/j.jbiotec.2018.11.022

Zhu, M., and Carta, G. (2014). Adsorption of Polyethylene-Glycolated Bovine Serum Albumin on Macroporous and Polymer-Grafted Anion Exchangers. J. Chromatogr. A. 1326, 29-38. doi:10.1016/j.chroma.2013.12.007

Zhu, Y., Ahluwalia, D., Chen, Y., Belakavadi, M., Katiyar, A., and Das, T. K. (2019). Characterization of Therapeutic Antibody Fragmentation Using Automated Capillary Western Blotting as an Orthogonal Analytical Technique. Electrophoresis 40, 2888-2898. doi:10.1002/elps.201900119

Conflict of Interest: The authors declare that the research was conducted in the absence of any commercial or financial relationships that could be construed as a potential conflict of interest.
Publisher's Note: All claims expressed in this article are solely those of the authors and do not necessarily represent those of their affiliated organizations, or those of the publisher, the editors and the reviewers. Any product that may be evaluated in this article, or claim that may be made by its manufacturer, is not guaranteed or endorsed by the publisher.

Copyright (c) 2021 Sánchez-Trasviña, Flores-Gatica, Enriquez-Ochoa, RitoPalomares and Mayolo-Deloisa. This is an open-access article distributed under the terms of the Creative Commons Attribution License (CC BY). The use, distribution or reproduction in other forums is permitted, provided the original author(s) and the copyright owner(s) are credited and that the original publication in this journal is cited, in accordance with accepted academic practice. No use, distribution or reproduction is permitted which does not comply with these terms. 